\title{
Introduction to the special issue "In-depth study of air pollution sources and processes within Beijing and its surrounding region (APHH-Beijing)"
}

Zongbo Shi ${ }^{1,2}$, Tuan Vu ${ }^{1}$, Simone Kotthaus ${ }^{3,4}$, Roy M. Harrison ${ }^{1, a}$, Sue Grimmond ${ }^{3}$, Siyao Yue ${ }^{5}$, Tong Zhu ${ }^{6}$, James Lee ${ }^{7,8}$, Yiqun Han ${ }^{6,9}$, Matthias Demuzere ${ }^{10}$, Rachel E. Dunmore ${ }^{7}$, Lujie Ren ${ }^{2,5}$, Di Liu ${ }^{1}$, Yuanlin Wang ${ }^{5,11}$, Oliver Wild $^{11}$, James Allan ${ }^{12,13}$, W. Joe Acton ${ }^{11}$, Janet Barlow ${ }^{3}$, Benjamin Barratt ${ }^{9}$, David Beddows ${ }^{1}$, William J. Bloss ${ }^{1}$, Giulia Calzolai ${ }^{14}$, David Carruthers ${ }^{15}$, David C. Carslaw ${ }^{7}, 16$, Queenie Chan ${ }^{9}$, Lia Chatzidiakou ${ }^{17}$, Yang Chen ${ }^{18}$, Leigh Crilley ${ }^{1}$, Hugh Coe ${ }^{12}$, Tie Dai ${ }^{5}$, Ruth Doherty ${ }^{19}$, Fengkui Duan ${ }^{20}$, Pingqing Fu ${ }^{2,5}$, Baozhu Ge $^{5}$, Maofa Ge ${ }^{21}$, Daobo Guan ${ }^{22}$, Jacqueline F. Hamilton ${ }^{7}$, Kebin He$^{20}$, Mathew Heal ${ }^{19}$, Dwayne Heard ${ }^{23}$, C. Nicholas Hewitt ${ }^{11}$, Michael Hollaway ${ }^{11}$, Min Hu${ }^{6}$, Dongsheng $\mathrm{Ji}^{5}$, Xujiang Jiang ${ }^{20}$, Rod Jones ${ }^{17}$, Markus Kalberer ${ }^{17, b}$, Frank J. Kelly ${ }^{9}$, Louisa Kramer ${ }^{1}$, Ben Langford ${ }^{24}$, Chun Lin ${ }^{19}$, Alastair C. Lewis ${ }^{7}$, Jie Li $^{5}$, Weijun Li ${ }^{25}$, Huan Liu ${ }^{20}$, Junfeng Liu ${ }^{26}$, Miranda Loh ${ }^{27}$, Keding Lu ${ }^{6}$, Franco Lucarelli ${ }^{14}$, Graham Mann ${ }^{28}$, Gordon McFiggans ${ }^{12}$, Mark R. Miller ${ }^{29}$, Graham Mills ${ }^{30}$, Paul Monk ${ }^{31}$, Eiko Nemitz $^{24}$, Fionna O'Connor ${ }^{32}$, Bin Ouyang ${ }^{11,17}$, Paul I. Palmer ${ }^{19}$, Carl Percival ${ }^{12, \mathrm{c}}$, Olalekan Popoola ${ }^{17}$, Claire Reeves $^{30}$, Andrew R. Rickard ${ }^{7,8}$, Longyi Shao $^{33}$, Guangyu Shi ${ }^{5}$, Dominick Spracklen ${ }^{28}$, David Stevenson ${ }^{19}$, Yele Sun $^{5}$, Zhiwei Sun ${ }^{34}$, Shu Tao ${ }^{26}$, Shengrui Tong ${ }^{21}$, Qingqing Wang ${ }^{5}$, Wenhua Wang ${ }^{33}$, Xinming Wang ${ }^{35}$, Xuejun Wang ${ }^{26}$, Zifang Wang ${ }^{5}$, Lianfang Wei ${ }^{5}$, Lisa Whalley ${ }^{23}$, Xuefang $\mathrm{Wu}^{1}$, Zhijun $\mathrm{Wu}^{6}$, Pinhua Xie ${ }^{36}$, Fumo Yang ${ }^{37}$, Qiang Zhang ${ }^{38}$, Yanli Zhang ${ }^{35}$, Yuanhang Zhang ${ }^{6}$, and Mei Zheng ${ }^{6}$

${ }^{1}$ School of Geography Earth and Environmental Sciences, the University of Birmingham, Birmingham, UK

${ }^{2}$ Institute of Surface-Earth System Science, Tianjin University, Tianjin, China

${ }^{3}$ Department of Meteorology, University of Reading, Reading, UK

${ }^{4}$ Institut Pierre Simon Laplace, École Polytechnique, Palaiseau, France

${ }^{5}$ Institute of Atmospheric Physics, Chinese Academy of Sciences, Beijing, China

${ }^{6}$ College of Environmental Sciences and Engineering, Peking University, Beijing, China

${ }^{7}$ Wolfson Atmospheric Chemistry Laboratories, Department of Chemistry, University of York, York, UK

${ }^{8}$ National Centre for Atmospheric Science, University of York, York, UK

${ }^{9}$ Analytical \& Environmental Sciences Division, King's College London, London, UK

${ }^{10}$ Department of Geography, Ruhr-University Bochum, Bochum, Germany

${ }^{11}$ Lancaster Environment Centre, Lancaster University, Lancaster, UK

${ }^{12}$ School of Earth and Environmental Sciences, The University of Manchester, Manchester, UK

${ }^{13}$ National Centre for Atmospheric Science, The University of Manchester, Manchester, UK

${ }^{14}$ Dipartimento di Fisica e Astronomia, University of Florence, Florence, Italy

${ }^{15}$ Cambridge Environmental Research Consultants, Cambridge, UK

${ }^{16}$ Ricardo Energy \& Environment, Harwell, Oxfordshire, UK

${ }^{17}$ Department of Chemistry, University of Cambridge, Cambridge, UK

${ }^{18}$ Chongqing Institute of Green and Intelligent Technology, Chinese Academy of Sciences, Chongqing, China

${ }^{19}$ School of Geosciences, University of Edinburgh, Edinburgh, UK

${ }^{20}$ School of Environment, Tsinghua University, Beijing, China

${ }^{21}$ Institute of Chemistry, Chinese Academy of Sciences, Beijing, China

${ }^{22}$ School of International Development, University of East Anglia, Norwich, UK

${ }^{23}$ Department of Chemistry, University of Leeds, Leeds, UK

${ }^{24}$ Centre for Ecology \& Hydrology, Penicuik, UK

${ }^{25}$ School of Earth Sciences, Zhejiang University, Hangzhou, China 
${ }^{26}$ College of Urban and Environmental Sciences, Peking University, Beijing, China

${ }^{27}$ Institute of Occupational Medicine (IOM), Edinburgh, UK

${ }^{28}$ School of Earth and Environment, University of Leeds, Leeds, UK

${ }^{29}$ Centre for Cardiovascular Science, Queen's Medical Research Institute, University of Edinburgh, Edinburgh, UK

${ }^{30}$ School of Environmental Studies, University of East Anglia, Norwich, UK

${ }^{31}$ Department of Chemistry, University of Leicester, Leicester, UK

${ }^{32}$ Hadley Centre, Met Office, Reading, UK

${ }^{33}$ State Key Laboratory of Coal Resources and Safe Mining \& College of Geosciences and Surveying Engineering, China University of Mining and Technology, Beijing, China

${ }^{34}$ School of Public Health, Capital Medical University, Beijing, China

${ }^{35}$ Guangzhou Institute of Geochemistry, Chinese Academy of Sciences, Guangzhou, China

${ }^{36}$ Anhui Institute of Optics and Fine optics, Chinese Academy of Sciences, Hefei, China

${ }^{37}$ Department of Environmental Science and Engineering, College of Architecture and Environment, Sichun University, Chengdu, China

${ }^{38}$ Department of Earth System Science, Tsinghua University, Beijing, China

${ }^{a}$ also at: Department of Environmental Sciences/Center of Excellence in Environmental Studies, King Abdulaziz University, P.O. Box 80203, Jeddah, Saudi Arabia

${ }^{b}$ now at: University of Basel, Department of Environmental Sciences, Klingelbergstrasse 27, Basel, Switzerland

${ }^{c}$ now at: Jet Propulsion Laboratory, 4800 Oak Grove Drive, Pasadena, CA, USA

Correspondence: Zongbo Shi (z.shi@bham.ac.uk)

Received: 10 September 2018 - Discussion started: 15 October 2018

Revised: 25 April 2019 - Accepted: 26 April 2019 - Published: 5 June 2019

\begin{abstract}
The Atmospheric Pollution and Human Health in a Chinese Megacity (APHH-Beijing) programme is an international collaborative project focusing on understanding the sources, processes and health effects of air pollution in the Beijing megacity. APHH-Beijing brings together leading China and UK research groups, state-of-the-art infrastructure and air quality models to work on four research themes: (1) sources and emissions of air pollutants; (2) atmospheric processes affecting urban air pollution; (3) air pollution exposure and health impacts; and (4) interventions and solutions. Themes 1 and 2 are closely integrated and support Theme 3, while Themes 1-3 provide scientific data for Theme 4 to develop cost-effective air pollution mitigation solutions. This paper provides an introduction to (i) the rationale of the APHH-Beijing programme and (ii) the measurement and modelling activities performed as part of it. In addition, this paper introduces the meteorology and air quality conditions during two joint intensive field campaigns - a core integration activity in APHH-Beijing. The coordinated campaigns provided observations of the atmospheric chemistry and physics at two sites: (i) the Institute of Atmospheric Physics in central Beijing and (ii) Pinggu in rural Beijing during 10 November-10 December 2016 (winter) and 21 May-22 June 2017 (summer). The campaigns were complemented by numerical modelling and automatic air quality and low-cost sensor observations in the Beijing megacity. In summary, the paper provides background information on the APHH-Beijing programme and sets the scene for more fo-
\end{abstract}

cused papers addressing specific aspects, processes and effects of air pollution in Beijing.

\section{Introduction}

Air pollution is one of the largest environmental risks. It is estimated that air pollution has led to 7 million premature deaths per year globally (WHO, 2016a, b) and over a million in China (GBD MAPS Working Group, 2016). Air pollution also has significant impact on the healthcare system and ecosystems, which cost about $0.3 \%$ of global GDP (OECD, 2016). Air-pollution-related sickness also reduces productivity, and severe haze leads to closure of transport systems, causing additional damage to the economy. Total economic losses related to China's $\mathrm{PM}_{2.5}$ (particulate matter with aerodynamic diameter equal to or less than $2.5 \mu \mathrm{m}$ ) pollution in 2007 amounted to 346 billion yuan (GBP 39 billion, approximately $1.1 \%$ of the national GDP) based on the number of affected Chinese employees whose work time in years was reduced because of mortality, hospital admissions and outpatient visits (Xia et al., 2016).

Considerable research effort has led to huge progress in understanding the sources and pollution processes in megacities in western countries, e.g. major interdisciplinary and multi-institutional programmes in Paris and London in the last few years (Beekmann et al., 2015; Bohnenstengel et al., 2014). Although air pollution in developed megacities some- 
times breaks country-specific limits and WHO guidelines, traditional London or Los Angeles type smogs which occurred in the early and mid-20th centuries are rare. In the developing countries, however, the rush to industrialisation and rapid growth in vehicle populations have led to serious air pollution problems that are more complex than the London or Los Angeles smogs.

Air pollution is particularly severe in developing megacities, such as Beijing, where pollutants from traditional sources, such as solid fuel combustion are mixed with those from modern vehicles (Guan et al., 2014), on top of regional pollution from industrial and other anthropogenic activities. Air pollution in Beijing is different from that in well-studied developed megacities, such as Paris and London, in a number of ways including the lack of diesel emissions in the inner city, the use of coal in surrounding rural areas for heating and domestic cooking (Tao et al., 2018), the high emissions of air pollutants in neighbouring provinces (Hebei and Tianjin) and the high oxidising power due to the complex chemistry (Zhang et al., 2009; Li et al., 2017; Lu et al., 2018). This makes Beijing a particularly interesting place to study as it provides an atmospheric environment with major contrasts to developed megacities such as London and Paris in which to investigate urban pollution processes.

Many research programmes have been initiated in Beijing to study the air pollution processes since the late 1990s. Earlier research programmes (e.g. early 2000) focused on primary emissions of $\mathrm{SO}_{2}, \mathrm{NO}_{2}, \mathrm{CO}, \mathrm{PM}_{10}$, volatile organic compounds and subsequently secondary pollutants such as ground-level ozone and secondary fine particles. This research contributed to the development of air pollution mitigation strategies introduced by the Beijing municipal government.

The Beijing Olympic Games (2008) offered additional incentives to improve air quality and this led to the funding of CAREBeijing (Campaigns of Air Pollution Research in Megacity Beijing and Surrounding Region) and other major programmes. The field campaigns were conducted in the summers of 2006, 2007 and 2008, with the objectives to learn the environmental conditions of the region, to identify and quantify the processes (transport and transformation) that led to the impact of the surrounding area on air quality in Beijing and to formulate policy suggestions for air quality improvement during the 2008 Beijing Olympic Games. Measures developed as a result of this and other programmes successfully improved air quality during the Olympic Games and provided valuable examples for developing air pollution control policy in other cities (Wang et al., 2010). CAREBeijing was later extended to CAREBeijing-NCP (Campaigns of Air Pollution Research in megacity Beijing and North China Plain), in which field campaigns were carried out in the summer of 2013 and 2014 to investigate the transport and transformation processes of air pollutants in the Beijing megacity and North China Plain. The results of CAREBeijing and CAREBeijing-NCP have been published in special issues of Atmospheric Chemistry and Physics (https://www.atmos-chem-phys.net/special_issue198.html, last access: 20 May 2019) and Journal of Geophysical Research-Atmospheres (https://agupubs.onlinelibrary.wiley. com/doi/toc/10.1002/(ISSN)2169-8996.CARBS1, last access: 20 May 2019). However, our understanding of sources and emissions of key air pollutants such as $\mathbf{P M}_{2.5}$ and ozone and the role of the interactions between physical and chemical processes in the development of pollution events in Beijing is still far from being accurate or complete. In addition, none of the abovementioned large programmes have been directly linked to health effect studies.

The adverse health effects of air pollution provide one of the key motivations to control air pollution. Research has shown that air pollution is one of the leading causes of the disease burden in China (GBD MAPS Working Group, 2016). Especially particulate pollution, the leading cause of severe air pollution events in China, has a significant impact on human health and is associated with high mortality (Q. Zhang et al., 2017), with a considerable proportion of this related to cardiorespiratory diseases (namely stroke, ischemic heart disease and chronic obstructive pulmonary disease) (Yang et al., 2013; Lozano et al., 2013). Despite this increasing evidence base, the adverse health impact of air pollution remains a complex issue. For instance, the risk assessment of disease burden due to air pollution in China has relied largely on the studies undertaken in Europe and North America, which may be subject to error due to the difference of race, lifestyle and air pollution settings (Lim et al., 2012). The marked change in air pollution sources and composition between the heating and non-heating seasons, and the differences between urban and rural areas may all lead to different biological responses in local populations. However, to date, such comparative investigations are largely lacking. A further limitation of such work is the lack of accurate personal exposure estimates which are crucial in high-quality health studies. This may be especially true when considering household air pollution from traditional biomass and coal stoves which may not be easily captured by typical outdoor monitoring instruments (Linn et al., 2001; Brook et al., 2002). Thus, understanding the health impact of air pollution in China remains a major challenge.

To address these issues, the UK Natural Environment Research Council (NERC), in partnership with the National Science Foundation of China (NSFC), UK Medical Research Council (MRC) and UK-China Innovation Newton Fund funded a major joint research programme - Atmospheric Pollution and Human Health in a Chinese Megacity (APHH-Beijing). APHH-Beijing is an integrated research programme, incorporating the capabilities and strengths of the UK and Chinese science communities, which is taking a multidisciplinary approach to investigating the sources, processes and health effects of air pollution in the Beijing megacity. The new scientific understanding underpins the de- 
velopment of interventions and solutions to improve air quality and reduce health impacts.

This special issue "In-depth study of air pollution sources and processes within Beijing and its surrounding region (APHH-Beijing)" documents the research outcomes of this APHH-Beijing programme, in particular the atmospheric measurement and modelling aspects.

This introduction paper describes the motivation and background of the APHH-Beijing programme and presents some of the background air quality and meteorological observations, particularly during the two intensive field campaigns. These campaigns form one of the core research activities within APHH-Beijing integrating the different themes/projects. We do not present the key scientific results of APHH-Beijing in this introduction (not an overview) paper, as much of the research activities are still ongoing and unpublished. Key findings will be published in the special issue to which this paper provides key background information.

\section{APHH-Beijing programme objectives}

The overall aim of APHH-Beijing is to better understand the sources, atmospheric transformations and health impacts of air pollutants in the Beijing megacity and to improve the capability of forecasting air quality and developing costeffective mitigation measures. Specific objectives are

- to determine the emission fluxes of key air pollutants and to measure the contributions of different sources, economic sectors and regional transport to air pollution in Beijing;

- to improve understanding of the processes by which pollutants are transformed or removed through transport, chemical reactions and photolysis, and the rates of formation and conversion of particulate matter (PM) via atmospheric reactions;

- to improve understanding on how the detailed properties of PM evolve and can influence their physical properties and behaviour in the atmosphere and elucidate the mechanisms whereby those properties may interact and give feedback on urban-scale and regional meteorology;

- to exploit new satellite observations and regional models to place the in situ campaigns into a wider context;

- to determine the exposure of Beijing inhabitants to key health-related pollutants using personal air pollution monitors and assess the association between air pollution exposure and key cardiopulmonary measures;

- to determine the contribution of specific activities, environments and pollution sources to the personal exposure of the Beijing population to air pollutants;
- to enhance our understanding of the health effects in susceptible individuals over time periods when there are large fluctuations in pollutants compared with normal controls and to identify health outcomes of air pollution; and

- to estimate economic loss due to both physical and mental impacts of air pollution and examine how Beijing can improve its air quality more cost-effectively.

\section{Research themes and integration within the APHH-Beijing programme}

The APHH-Beijing programme has four themes to address the specific objectives outlined in Sect. 2 and is delivered through five inter-related research projects:

- Theme 1 - sources and emissions: delivered by the AIRPOLL-Beijing (Source and Emissions of Air Pollutants in Beijing) project;

- Theme 2 - atmospheric processes: delivered by the AIRPRO (The integrated Study of AIR Pollution PROcesses in Beijing) project;

- Theme 3 - health effects: delivered by two projects the AIRLESS (Effects of AIR pollution on cardiopuLmonary disEaSe in urban and peri-urban reSidents in Beijing) and the APIC-ESTEE (Air Pollution Impacts on Cardiopulmonary Disease in Beijing: An integrated study of Exposure Science, Toxicogenomics and Environmental Epidemiology) projects; and

- Theme 4 - solutions: delivered by the INHANCE (Integrated assessment of the emission-healthsocioeconomics nexus and air pollution mitigation solutions and interventions in Beijing) project.

\subsection{Research themes}

\subsubsection{Theme 1: sources and emissions}

Theme 1 (AIRPOLL) aims to quantify the emission fluxes of key air pollutants in Beijing and the contributions of different sources, economic sectors and regional transport to air pollution in Beijing. The project has carried out two major field observation campaigns jointly with the AIRPRO and AIRLESS projects (Sect. 3.1.2 and 3.1.3) during NovemberDecember 2016 and May-June 2017. The campaigns were carried out at two sites - one within Beijing (at the Institute of Atmospheric Physics (IAP) meteorological tower site) and the other in the local region (the rural Pinggu site; see Sect. 4.1 for site information).

During the intensive campaigns, the project measured the fluxes of particulate and gaseous air pollutants from groundlevel sources by sampling on the meteorological tower 
( $325 \mathrm{~m}$ ) at the IAP site, which is compared with emissions estimates taken from the inventory for Beijing. This was complemented by top-down fluxes inferred from satellite data for nitrogen dioxide, sulfur dioxide and formaldehyde, the latter indicative of volatile organic compound (VOC) oxidation processes (Palmer et al., 2003; Fu et al., 2007). Through these means, the emissions inventory is being tested, allowing revisions which are being incorporated into the atmospheric modelling work.

AIRPOLL also made very detailed online and offline measurements of airborne particles. This included continuous measurements of size distributions from $1 \mathrm{~nm}$ to $>10 \mu \mathrm{m}$ diameter. Large molecules and molecular clusters were also measured by high-resolution mass spectrometry, which aims to better understanding atmospheric nucleation processes. The project has monitored the chemical composition of particles in real time by aerosol mass spectrometry and analysed the time-integrated particle samples offline for major and minor constituents, including organic molecular markers. AIRPOLL determined the carbon-14 in water-soluble organic carbon, water-insoluble organic carbon and elemental carbon in selected time-integrated particle samples with an aim to differentiate fossil and non-fossil particulate carbon. These data are being brought together for use in receptor modelling of PM sources, which are compared with other estimates of source contributions to PM concentrations. Measured ground-level concentrations both from our campaign sites and the Beijing monitoring network, together with vertical gradient observations at the tower and source apportionment results, are compared with the predictions of a chemistry-transport model and used to provide a clear distinction between advected regional pollution and the impact of local sources. Divergences between measured and modelled pollutant concentrations will be used to provide critical evaluation of emissions inventories, which will be enhanced iteratively to improve knowledge of the sources and emissions of pollutants affecting air quality in Beijing.

During the campaigns, AIRPOLL and AIRLESS measured the concentrations of key tracers and reactive species indicative of sources and chemical pathways at the groundlevel sites, which complements AIRPOLL observations.

\subsubsection{Theme 2: atmospheric processes}

Theme 2 (AIRPRO) aims to study the fundamental chemical and physical processes controlling gas and particle pollution, localised meteorological dynamics and the links between them within Beijing's atmosphere. Central to the project were the intensive in situ measurements at the IAP meteorological tower $(325 \mathrm{~m})$ site, jointly carried out with the AIRPOLL project. AIRPRO made comprehensive and detailed local observations of both primary emitted chemicals and particles, radical intermediates and secondary products, for periods of contrasting local and regional emissions, solar insolation and air temperature. These data allow the perfor- mance of local and regional models of air pollution to be robustly tested, both for final regulated pollutant outcomes and at a more mechanistic level.

Observations made with instruments from multiple Chinese and UK research groups included complementary measurements of key precursor trace gases such as $\mathrm{NO}_{x}, \mathrm{HONO}$, $\mathrm{SO}_{2}, \mathrm{CO}, \mathrm{O}_{3}$, VOCs and semi-volatile organic compounds (SVOCs), gas-phase radicals such as $\mathrm{OH}, \mathrm{HO}_{2}, \mathrm{RO}_{2}, \mathrm{NO}_{3}$ and PM including chemical (both online and offline analyses), biological, physical and optical properties. Through multiple co-located surface measurements, there were both instrumental redundancy (e.g. for equipment failures) and capacity to evaluate through intercomparison some hard-tomeasure atmospheric free radicals and gases such as $\mathrm{OH}$, $\mathrm{HO}_{2}, \mathrm{~N}_{2} \mathrm{O}_{5}, \mathrm{HCHO}$ and other oxygenated VOCs. The project determined the local in situ chemical processing of air pollution in the contrasting winter/summertime periods alongside overall atmospheric reactivity, both during the day and at night, through a combination of modelling and proxy measurements such as measured ozone production efficiency and $\mathrm{OH}$ reactivity.

The IAP tower allowed vertical profiles of key pollutants up to $320 \mathrm{~m}$ to be obtained and, with additional remote sensing of composition and meteorology, provided insight into boundary layer stability and evolution over the diurnal cycle. Quantification of shallow mixed layers proved to be vital for explaining local surface in situ chemical processing and also street-level concentrations of relevance to exposure. The potentially significant vertical gradients anticipated in some chemicals and PM properties were further quantified using instruments installed on the tall tower and via profiling gondola measurements. The combined datasets, surface and profiles provide the basis for evaluation of model performance and notably comparisons for those intermediates that provide indicators of whether secondary pollution production is being correctly simulated.

\subsubsection{Theme 3: health effects}

Health effects of air pollution are studied by two projects AIRLESS and APIC-ESTEE. AIRLESS aims to advance air quality and health research in Beijing by bringing together two fields of research that have made rapid advancements in recent years: measurements of a wide range of pulmonary and cardiovascular biomarkers in a panel study and personal monitoring of multiple air pollutants with high spatiotemporal resolution by sensor technology. AIRLESS is also benefiting from the use of an extensive range of pollution metrics and source apportionment results from the AIRPOLL and AIRPRO projects. These data are being compared with our personal air quality assessments and used to further understanding of the nature of the air pollution exposures of residents and how this relates to their health status.

APIC-ESTEE aims to evaluate the impacts of air pollution on cardiopulmonary health through an integrated study 
of exposure, epidemiology and toxicology/toxicogenomics. APIC-ESTEE has investigated the relationship between ambient air pollution and personal exposures. This is being used to estimate personal exposures for epidemiological analyses of long-term health impacts in a cohort study and of shortterm effects (i.e. biomarkers, blood pressure, heart rhythm and peak flow) in a panel study. APIC-ESTEE also studied the real-world exposure reduction and health benefit potential of face masks, a commonly used personal-level intervention seen in Beijing. Furthermore, to complement the human based studies into mechanisms of action, APIC-ESTEE has conducted in vivo analyses of mechanistic effects and early life toxicogenomics/metabonomics.

\subsubsection{Theme 4: solutions}

Theme 4 (INHANCE) aims to quantitatively evaluate the performance of China's current air pollution policies and develop cost-effective solutions to mitigate the impact of air pollution in the Beijing megacity. INHANCE considered not only the physical and mental health impacts and direct economic impact but also the cascading indirect economic losses that occurred through inter-industrial and interregional linkages on the supply side of the economy. INHANCE has established and evaluated interactive relationships among exposure, vulnerability, impact on health, implications for industry and economic consequences. INHANCE has compared and qualitatively assessed air quality policies between Beijing and other cities, undertaken policy performance assessment modelling, utilised techno-economic inventories for anti-pollution measures to conduct microeconomic cost-benefit analysis of new policies, measured health and macroeconomic costs and benefits in mitigating air pollution, and transformed evidence generated into practical emission alleviation pathways. On these bases, INHANCE will deliver recommendations regarding integrated policy design and an assessment for policy cost-effectiveness.

\subsection{Integration between the themes and novelty of the APHH-Beijing programme}

The APHH-Beijing programme is highly integrated to ensure the biggest possible scientific and policy impacts. One of the most significant integration activities between the different themes is the coordinated joint field campaigns at an urban and a rural site in Beijing for Themes 1, 2 and 3 to fully exploit the complementary measurements and expertise by different research groups, which is described in the following sections. Themes 1 and 2 are closely related and in many senses inseparable. For example, our knowledge of the sources and emissions is essential to interpret the processes, while knowledge on the atmospheric physical and chemical processes will help us to more accurately quantify the source emissions both via actual flux-based measurements and model evaluation of the emission inventories. Further- more, to ensure integration, Themes 1 and 2 co-located their rural site at Pinggu as that was selected for the Theme 3 panel study.

Modelling of airborne concentrations of pollutants within Themes 1 and 2 is fully integrated, primarily via the UKCA (UK Chemistry and Aerosol), NAQPMS (Nested Air Quality Prediction Model System) and GEOS-Chem models. The models simulate spatial and temporal variations of key air pollutants and are being evaluated using the new observations of pollutant emission fluxes, updated emission inventories, three-dimensional air quality low-cost-sensor observations, comprehensive composition and physics measurements, as well as new process understandings generated from the APHH-Beijing programme. Furthermore, in Themes 1 and 2, ADMS (Atmospheric Dispersion Modelling System) modelling results for the campaign periods facilitate the estimation of population exposure in Theme 3. Outcomes of Themes 1, 2 and 3 help to provide Theme 4 with a more accurate estimate of pollution costs and to develop cost-effective air pollution control measures in Beijing.

The third stream of integration activities involves regular APHH-Beijing programme science and stakeholder engagement meetings to stimulate collaboration and knowledge transfer between different themes and stakeholders. Furthermore, sharing of data was made available via a dedicated depository in Centre for Environmental Data Analysis (http://catalogue.ceda.ac.uk/ uuid/7ed9d8a288814b8b85433b0d3fec0300, last access: 20 May 2019). All data in the depository will be made publicly available by the end of 2022 .

Together, this interdisciplinary APHH-Beijing programme delivers key scientific values and innovation, including

1. validation of the bottom-up emission inventories by using novel eddy covariance emission flux observations from the IAP meteorological tower, integrated with satellite retrievals and numerical modelling;

2. improvement in understanding of air pollution processes through comprehensive observations of atmospheric gaseous and aerosol species integrated with atmospheric physics measurements; and

3. identification of the sources of air pollution that cause largest adverse human health effects by carrying out novel cardiovascular health indicator measurements, integrated with personal exposure, fixed station source apportionment studies and high-resolution air quality modelling.

\section{Overview of the joint field campaigns}

The two intensive campaigns took place from 10 November to 10 December 2016 and 20 May to 22 June 2017. The campaigns were carried out at both urban and rural sites. 


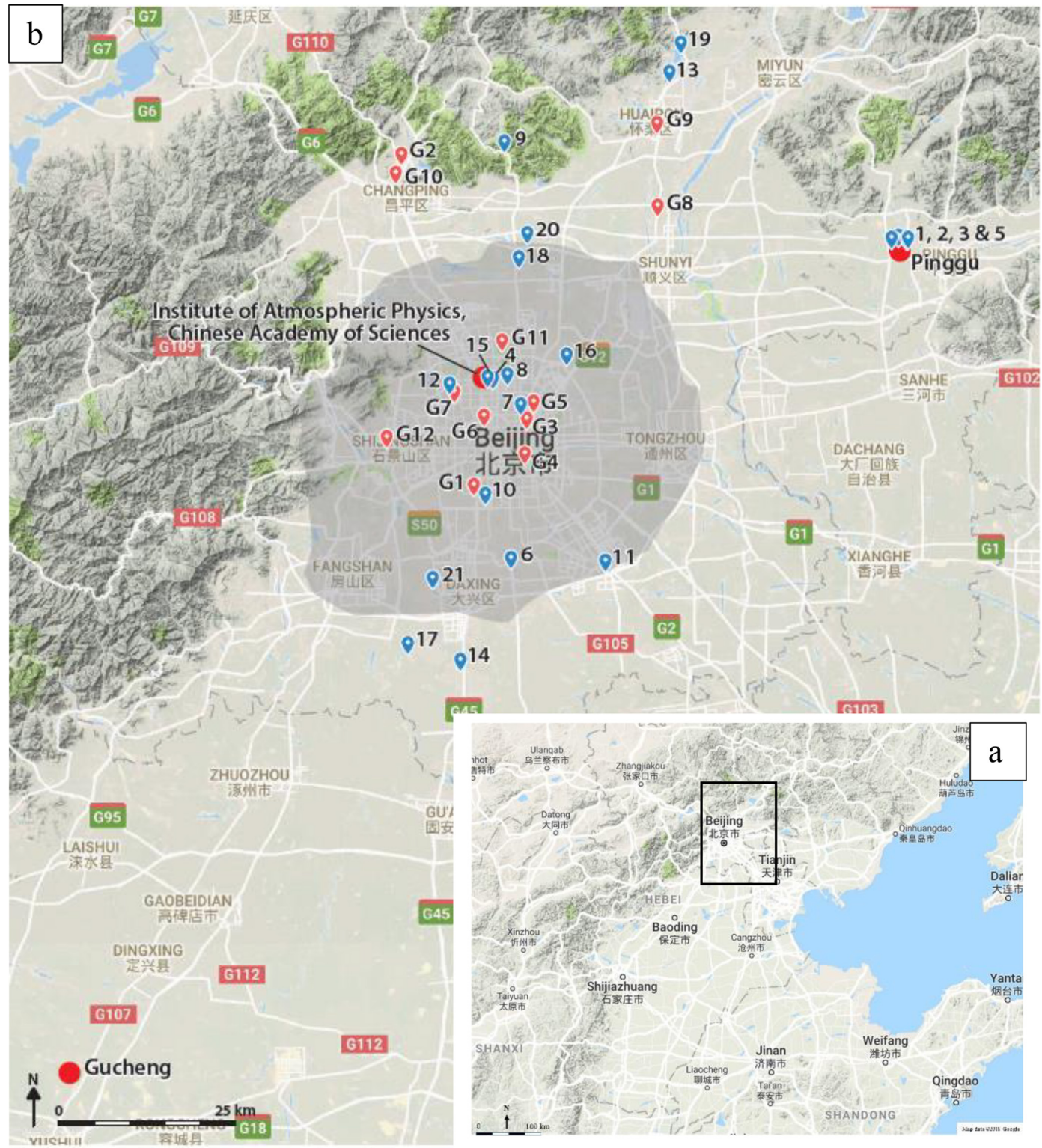

Figure 1. Study area topography (source: Google Maps) of the Beijing-Tianjin-Hebei region (a) with the rectangle showing enlarged study area; locations of measurement sites (Institute of Atmospheric Physics (IAP) - urban Beijing; Pinggu - rural Beijing; and Gucheng - upwind site in the Hebei province), SNAQ (Sensor Network for Air Quality) box sites (red symbols) and the 12 national air quality monitoring stations (G1 to G12, blue symbols) (b). The shaded area shows the Beijing build-up area. (Source: a and b - Google Maps topographic background imagery). G1: Wanshou Xigong; G2: Dingling (Ming Tombs); G3: Dongsi; G4: Tiantan; G5: Nongzhanguan; G6: Guanyuan; G7: Haidian Wanliu; G8: Shunyicheng; G9: Huairouzhen; G10: Changpingzhen; G11: Aoti Zhongxin (Olympic Park); G12: Gucheng. Categories: urban: G1, G3, G4, G5, G6, G7, G8, G11, G12; suburban: G9, G10; rural: G2.

\subsection{Site information}

The winter campaign had two main sites. The urban site $\left(39^{\circ} 58^{\prime} 33^{\prime \prime} \mathrm{N} 116^{\circ} 22^{\prime} 41^{\prime \prime} \mathrm{E}\right)$ is located in the tower section of the IAP, Chinese Academy of Sciences, where the $325 \mathrm{~m}$ meteorological tower is located. The site, between the fourth and third north ring roads of Beijing (Fig. 1), is in a residential area. Typical of central Beijing, there are various roads nearby. To the south, north and west ends there are roads about $150 \mathrm{~m}$ away. On site, there are two to three floor buildings to the south, and the east and west ends of the tower are surrounded by small trees and grass. There is a canal right to the north of the site. Further to the west is a park covered mainly by conifer pine trees (Yuan Dynasty Wall Heritage Park).

The rural Pinggu site in Xibaidian village $\left(40.17^{\circ} \mathrm{N}\right.$, $117.05^{\circ} \mathrm{E}$ ) in north-eastern Beijing was collocated with the 
AIRLESS project cohort. Xibaidian village is about $4 \mathrm{~km}$ north-west of the Pinggu town centre and about $60 \mathrm{~km}$ from IAP. There are several similar small villages nearby. The monitoring station and the clinic used an unoccupied house at the north end of the village away from significant local combustion sources. A two-lane road is about $300 \mathrm{~m}$ north of the site. With no centralised heating infrastructure available, residents mainly use coal and biomass for heating and cooking in individual homes.

In the summer, an additional site was operated in Gucheng $\left(39.2^{\circ} \mathrm{N} 115.7^{\circ} \mathrm{E}\right)$, Dingxing County, Hebei province. This site, about $120 \mathrm{~km}$ to the south-west of central Beijing, is on one of the main high-pollutant transport pathways from the Hebei province to Beijing from the south-west. The site is in a meteorological observatory surrounded by farm fields. The nearest town is about $10 \mathrm{~km}$ to the north-east. The nearest road is $500 \mathrm{~m}$ to the north and the nearest village $\sim 1 \mathrm{~km}$ to the west. Several villages are located around the site.

In addition to the two highly instrumented urban (IAP) and rural (Pinggu) sites, 21 SNAQ (Sensor Network for Air Quality) boxes, which measure $\mathrm{CO}, \mathrm{NO}, \mathrm{NO}_{2}, \mathrm{CO}_{2}, \mathrm{O}_{x}$, sizeresolved particulates $(0.38-17.4 \mu \mathrm{m})$, temperature, relative humidity, wind speed and direction (Popoola et al., 2018), were deployed during the summer and winter campaigns across the urban and rural areas of Beijing to map air pollutant variations (red tags; Fig. 1). Six additional SNAQ boxes were deployed at six different heights $(8,32,102,160,260$ and $320 \mathrm{~m}$ ) on the IAP tower from 9 to 23 November 2016 and 25 January to 31 December 2017.

Figure 1 also shows the location of the 12 national air quality monitoring stations. Hourly data for criteria air pollutants $\left(\mathrm{PM}_{2.5}, \mathrm{PM}_{10}, \mathrm{SO}_{2}, \mathrm{NO}_{2}, \mathrm{CO}\right.$ and $\left.\mathrm{O}_{3}\right)$ from January 2013 to December 2017 from the stations were also obtained from official sources. The closest air quality station to the urban IAP site is about $3 \mathrm{~km}$ away at the Olympic Park (G11; Fig. 1).

\subsection{Instrumentation}

\subsubsection{Urban site}

Table 1 lists all instruments deployed during the campaigns at the IAP site. Most instruments ran during both campaigns. A majority of the instruments were situated in the nine containers, which were at ground level on the campus grass. A number of online instruments and high-volume PM samplers were also deployed at different heights on the meteorological tower. Vertical profile measurements of atmospheric species including HONO were made during pollution events using baskets attached to the tower. Additional online measurements and offline PM samplers were deployed at ground level, on the roof of a two-storey building to the west (WB) and in a third-floor laboratory at the south end of the campus. In addition, high-, medium- and low-volume PM samplers were placed on the roof of WB for offline characterisation and source apportionment.

\subsubsection{Rural sites}

At Pinggu, online instruments (Table 2) were run within an air-conditioned room on the ground floor with inlets on top of the building. High-, medium- and low-volume PM samplers were deployed on a newly modified flat roof of the singlestorey building.

At Gucheng (summer only), a high-volume Digitel sampler and a single particle sampler were set up on a deserted basketball court. An aethalometer AE33 was located on top of a container at the edge of the basketball court. $\mathrm{CO}$ and $\mathrm{O}_{3}$ were also measured in a nearby container.

\subsection{Synoptic-scale meteorology during the field campaigns}

Synoptic circulation patterns (e.g. horizontal advection and wet deposition) play a key role in the variations of air quality in Beijing (Miao et al., 2017; Wu et al., 2017; Zhang et al., 2012). To provide the synoptic context of the APHH-Beijing observations, the daily mesoscale flow patterns have been classified and put into context using a 30-year climatology (Sect. 5.4).

Circulation types (CTs) are classified using the software produced by the COST Action 733 "Harmonisation and Applications of Weather Type Classifications for European regions" (Philipp et al., 2010) with (ECMWF reanalysis) ERAInterim $6 \mathrm{~h} 925 \mathrm{hPa}$ geopotential reanalysis data (Dee et al., 2011) at its native $0.75^{\circ}$ spatial resolution for the domain of interest $\left(31-49^{\circ} \mathrm{N}, 103-129^{\circ} \mathrm{E}\right)$ centred on Beijing $\left(40^{\circ} \mathrm{N}\right.$, $\left.116.5^{\circ} \mathrm{E}\right)$ covering the period 1988-2017. ERA-Interim $10 \mathrm{~m}$ $U$ and $V$ wind components are used to facilitate the interpretation of the flow patterns. Of the COST733 methods (Huth et al., 2008; Philipp et al., 2010, 2016; Tveito and Huth, 2016), two are used: T-Mode PCA (principal component analysis) and SANDRA (simulated annealing and diversified randomisation clustering). The former has been used in Beijing previously (e.g. Miao et al., 2017; Zhang et al., 2012). The latter is considered to perform well in clustering pressure fields and discriminating environmental variables (e.g. Demuzere et al., 2011; Philipp et al., 2016). Classification is performed with the number of CTs ranging from 7 to 18 . A total of 11 CTs from the SANDRA method are selected (Fig. 2; Table 3) to adequately represent the general flow conditions around Beijing during the 30-year climatology period (Beck and Philipp, 2010).

As expected, the CTs that occurred during the two field campaign periods are different (Fig. 3). During the winter field campaign, the most frequent circulation type was $\mathrm{CT}$ 11 ( $26 \%$ of the $6 \mathrm{~h}$ periods) which was often preceded by a period of CT 9 (total 13\%). Circulation types 9-11 are associated with air masses that may stagnate over the Beijing urban area (Fig. 2). CT 1 (accounting for $12 \%$ of the time) and CT $2(17 \%)$ are associated with the Asian winter monsoon which brings cold and dry air masses to eastern China. 
Table 1. Overview of measurements in APHH-Beijing at the urban site.

\begin{tabular}{|c|c|c|c|}
\hline Instrument & Measurements & Institute & References \\
\hline \multicolumn{4}{|l|}{ Container 1} \\
\hline FAGE & $\mathrm{OH}$ (chem and wave) $)^{\mathrm{c}}, \mathrm{HO}_{2}, \mathrm{RO}_{2}$ & Leeds & Whalley et al. (2010) \\
\hline $\mathrm{OH}$ reactivity & $\mathrm{OH}$ reactivity & Leeds & Stone et al. (2016) \\
\hline Spectral radiometer & Photolysis rates & Leeds & Bohn et al. (2016) \\
\hline Filter radiometer & $J\left(\mathrm{O}^{1} \mathrm{D}\right)$ & Leeds & Bohn et al. (2016) \\
\hline Dew point hygrometer & Water vapour & Leeds & Whalley et al. (2010) \\
\hline Davis met station & Wind speed, direction, temp, $\mathrm{RH}$, pressure & Leeds & \\
\hline Vaisala CL31 ALC ceilometer ${ }^{\mathrm{a}}$ & Cloud-base height, mixing height, attenuated backscatter profiles & Reading & Kotthaus and Grimmond (2018a) \\
\hline Personal air monitors (PAMS) & $\mathrm{CO}, \mathrm{NO}, \mathrm{NO}_{2}, \mathrm{PM}_{1}, \mathrm{PM}_{10}, \mathrm{PM}_{2.5}$ & Cambridge & Moore et al. (2016) \\
\hline MicroPEMs & Personal PM exposure & IOM & Sloan et al. (2016) \\
\hline \multicolumn{4}{|l|}{ Container 2} \\
\hline DC-GC-FID & $\mathrm{C}_{2}-\mathrm{C}_{7}$ VOCs and oVOCs & York & Hopkins et al. (2011) \\
\hline GCxGC FID & $\mathrm{C}_{6}-\mathrm{C}_{13}$ VOCs and oVOCs & York & Dunmore et al. (2015) \\
\hline TEI $42 \mathrm{i}$ & NO & Birmingham & \\
\hline Teledyne CAPS & $\mathrm{NO}_{2}$ & York & \\
\hline TEI $42 \mathrm{c}$ & Total $\mathrm{NO}_{y}$ & York & \\
\hline TEI 49i & $\mathrm{O}_{3}$ & York & \\
\hline TEI 43i & $\mathrm{SO}_{2}$ & York & \\
\hline Sensor box & $\mathrm{CO}$ & York & Smith et al. (2017) \\
\hline BBCEAS & $\mathrm{HONO}, \mathrm{NO}_{3}, \mathrm{~N}_{2} \mathrm{O}_{5}$ & Cambridge & Le Breton et al. (2014) \\
\hline \multicolumn{4}{|l|}{ Container 3} \\
\hline LOPAP & HONO & Birmingham & Crilley et al. (2016) \\
\hline LIF HCHO & $\mathrm{HCHO}$ & Leeds & Cryer et al. (2016) \\
\hline LOPAP & HONO & IC-CAS & Zhang et al. (2019) \\
\hline GC-MS & Organic nitrates & East Anglia & Mills et al. (2016) \\
\hline ROS online analyser & Reactive oxygen species & Cambridge & Wragg et al. (2016) \\
\hline \multicolumn{4}{|l|}{ Container $4^{\mathrm{b}}$} \\
\hline FAGE & $\mathrm{OH}$ (wave) ${ }^{\mathrm{c}}, \mathrm{HO}_{2}$ & Peking & Lu et al. (2012) \\
\hline FAGE & $\mathrm{OH}(\mathrm{chem})^{\mathrm{c}}$ & Peking & Tan et al. (2017) \\
\hline TEI $42 \mathrm{i}$ & NO & Peking & Tan et al. (2017) \\
\hline Teledyne CAPS & $\mathrm{NO}_{2}$ & Peking & \\
\hline TEI 42c with Moly converter & $\mathrm{NO}_{2}$ & Peking & \\
\hline TEI $49 \mathrm{i}$ & $\mathrm{O}_{3}$ & Peking & \\
\hline TEI & $\mathrm{CO}$ & Peking & \\
\hline Spectral radiometer & Photolysis rates & Peking & \\
\hline GC-ECD & PAN & Peking & Zhang et al. (2011) \\
\hline GC-MS & VOCs & Peking & M. Wang et al. (2015) \\
\hline \multicolumn{4}{|l|}{ Container $5^{b}$} \\
\hline H-TDMA/V-TDMA & Hygroscopicity/volatility & Peking & Wu et al. (2013) \\
\hline $\mathrm{SMPS}+\mathrm{APS}$ & Particle number size distribution & Peking & Wu et al. (2016) \\
\hline Particle size magnifier & Size distribution of $<3 \mathrm{~nm}$ particles & Peking & Vanhanen et al. (2011) \\
\hline IGAC-IC & Water-soluble ions & Peking & Yu et al. (2018) \\
\hline Xact & Metal & Peking & Yu et al. (2018) \\
\hline Sunset OC/EC & $\mathrm{EC} / \mathrm{OC}$ & Peking & Y. Zhang et al. (2017) \\
\hline \multicolumn{4}{|l|}{ Container 6} \\
\hline IBBCEAS & $\mathrm{HONO}, \mathrm{NO}_{2}$ & AIOFM & Duan et al. (2018) \\
\hline CRDS & $\mathrm{NO}_{3}$ and $\mathrm{N}_{2} \mathrm{O}_{5}$ & AIOFM & Li et al. (2018) \\
\hline Nitrate Api-ToF-CIMS & Organics, clusters (HOMs) & Birmingham & Junninen et al. (2010) \\
\hline SMPS & Particle size distribution & Birmingham & Shi et al. (1999) \\
\hline Particle size magnifier & Size distribution of $<3 \mathrm{~nm}$ particles & Birmingham & Vanhanen et al. (2011) \\
\hline
\end{tabular}


Table 1. Continued.

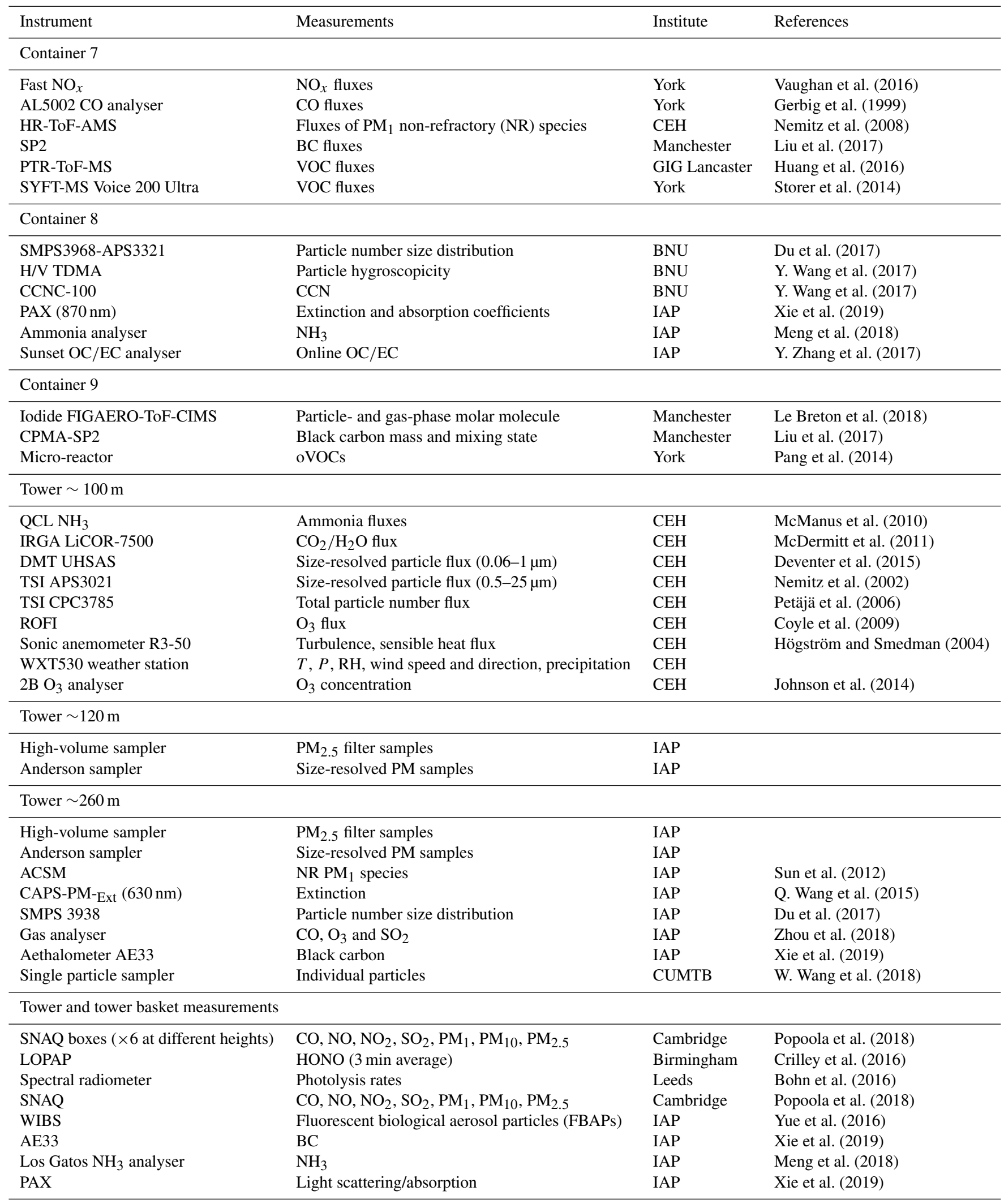


Table 1. Continued.

\begin{tabular}{|c|c|c|c|}
\hline Instrument & Measurements & Institute & References \\
\hline \multicolumn{4}{|l|}{ IAP ground } \\
\hline High-volume sampler & $\mathrm{PM}_{2.5}$ filter samples & Peking & \\
\hline Four-channel sampler & $\mathrm{PM}_{2.5}$ filter samples & Peking & \\
\hline High-volume sampler & High-time-resolution $\mathrm{PM}_{2.5}$ filter samples & York & \\
\hline FDMS+Thermo Scientific 1405-DF & Online $\mathrm{PM}_{2.5}$ mass concentration & IAP & \\
\hline \multicolumn{4}{|l|}{ IAP roof/lab } \\
\hline Partisol sampler & $\mathrm{PM}_{2.5}+\mathrm{PM}_{2.5-10}$ & Birmingham & Taiwo et al. (2014) \\
\hline Streaker sampler & Hourly elements in $\mathrm{PM}_{2.5}$ and $\mathrm{PM}_{2.5-10}$ & Birmingham & Taiwo et al. (2014) \\
\hline Digitel high-volume & $\mathrm{PM}_{2.5}$ daily & IAP & \\
\hline Digitel high-volume & $\mathrm{PM}_{1}$ - 3-hourly & IAP & \\
\hline Andersen sampler & Size-resolved PM & IAP & \\
\hline WIBS & Fluorescent biological particles & IAP & Yue et al. (2016) \\
\hline CAPS-NO 2 & $\mathrm{NO}_{2}$ & IAP & Ge et al. (2013) \\
\hline Aethalometer AE33 & Black carbon & IAP & Xie et al. (2019) \\
\hline CAPS-PM $_{\text {SSA }}(630 \mathrm{~nm})$ & Extinction, scattering & IAP & Han et al. (2017) \\
\hline HR-ToF-AMS & NR-PM species & IAP & Sun et al. (2016) \\
\hline SP-AMS & Refractory BC and coated aerosol composition & & J. Wang et al. (2017) \\
\hline Iodide FIGAERO- ToF-CIMS & Particle- and gas-phase molar molecule & IAP & Zhou et al. (2018) \\
\hline Single particle sampler & Individual particles & CUMTB & Wang et al. (2018) \\
\hline
\end{tabular}

Institution names: AIOFM is Anhui Institute of Fine Optics and Mechanics; BNU is Beijing Normal University; CEH is Centre for Ecology and Hydrology; CUMTB is China University of Mining and Technology (Beijing); GIG is Guangzhou Institute of Geochemistry, Chinese Academy of Sciences; NUIST is Nanjing University of Information Science and Technology; IC-CAS is Institute of Chemistry, Chinese Academy of Sciences. ${ }^{\text {a }}$ Deployment of instrument from 10 November 2016 to

25 June 2017. ${ }^{\mathrm{b}}$ Winter campaign only. ${ }^{\mathrm{c}} \mathrm{OH}$ wave and $\mathrm{OH}$ chem refer to the methods used to obtain the background signal for the FAGE instruments which are equipped with a scavenger inlet.

Table 2. Overview of measurements at the Pinggu site.

\begin{tabular}{|c|c|c|c|}
\hline Instruments & Measurements & Institute & Reference \\
\hline Thermo gas analysers & $\mathrm{NO}_{x} / \mathrm{SO}_{2} / \mathrm{CO} / \mathrm{O}_{3}$ & Peking & Liang et al. (2017) \\
\hline BAM 1020 & $\mathrm{PM}_{2.5}$ mass concentration & Peking & Liang et al. (2017) \\
\hline High-volume sampler & $\mathrm{PM}_{2.5}$ samples & IAP & Zhao et al. (2018) \\
\hline Medium-volume sampler & $\mathrm{PM}_{2.5}$ samples & IAP & Zhao et al. (2018) \\
\hline Low-volume Andersen sampler & Size-resolved PM samples & IAP & Zhao et al. (2018) \\
\hline Partisol sampler & $\mathrm{PM}_{2.5}$ samples & Birmingham & Taiwo et al. (2014) \\
\hline Streaker sampler & Hourly elements in $\mathrm{PM}_{2.5}$ and $\mathrm{PM}_{2.5-10}$ & Birmingham & Taiwo et al. (2014) \\
\hline High-volume sampler & Filters of $\mathrm{PM}_{2.5}$; high time resolution & Birmingham & \\
\hline Four-channel sampler & $\mathrm{PM}_{2.5}$ samples & Peking & Liang et al. (2017) \\
\hline Thermo MAAP & Online black carbon & Peking & Lin et al. (2011) \\
\hline Sunset OC/EC analyser & Online OC/EC & Peking & Han et al. (2014) \\
\hline Xact & Hourly metals & Peking & Yu et al. (2018) \\
\hline ToF-ACSM & NR-chemical composition (summer) & Peking & Sun et al. (2012) \\
\hline Thermo Metone & Meteorological parameters & Peking & Liang et al. (2017) \\
\hline SNAQ & Meteorological parameters & Cambridge & Popoola et al. (2018) \\
\hline SP-AMS & Individual particle composition & CQIGIT & Chen et al. (2017) \\
\hline SMPS & Size distribution & Tsinghua & Wang et al. (2009) \\
\hline ACSM & NR-chemical composition (winter) & Tsinghua & Li et al. (2016) \\
\hline
\end{tabular}

CQIGIT is Chongqing Institute of Green and Intelligence Technology, Chinese Academy of Sciences. 


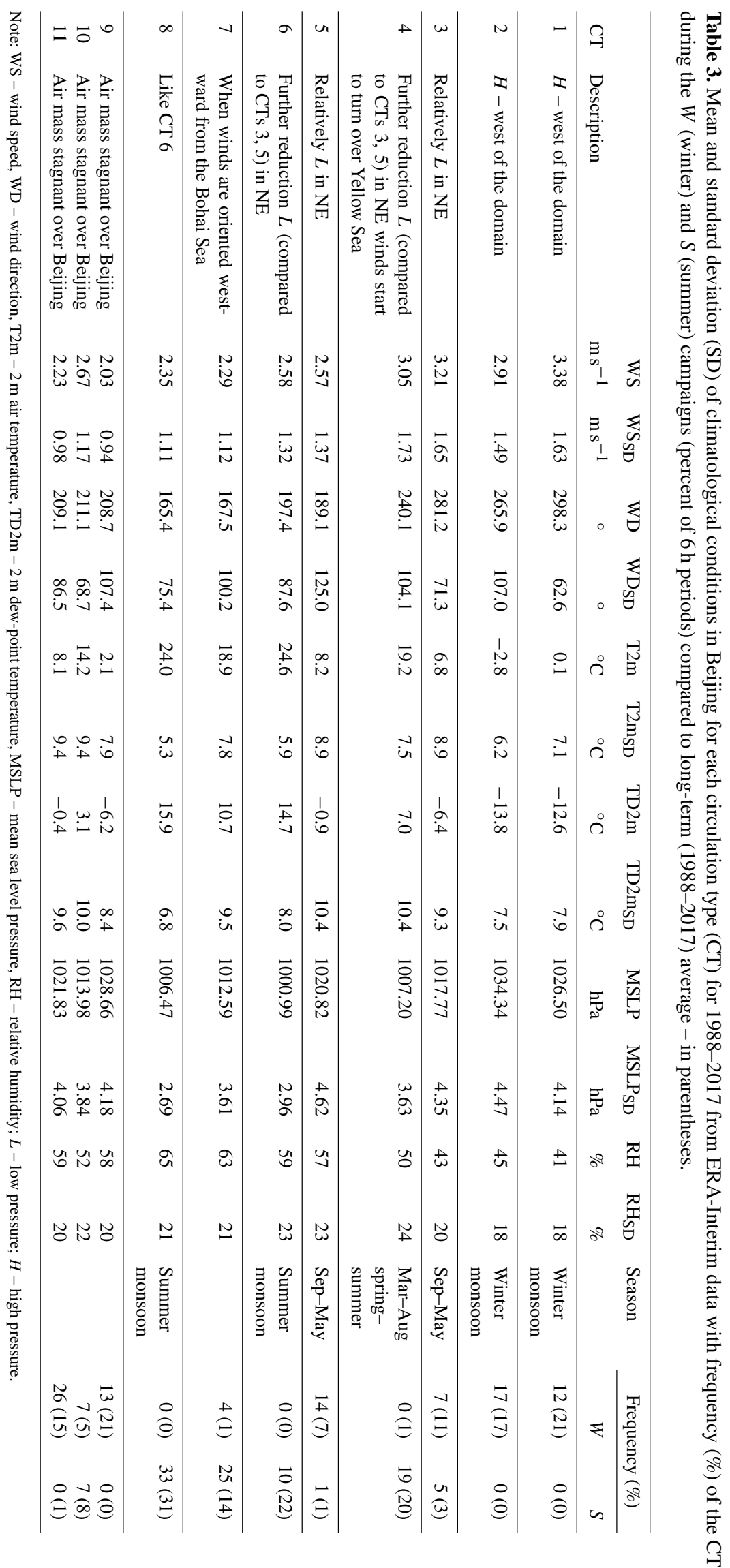




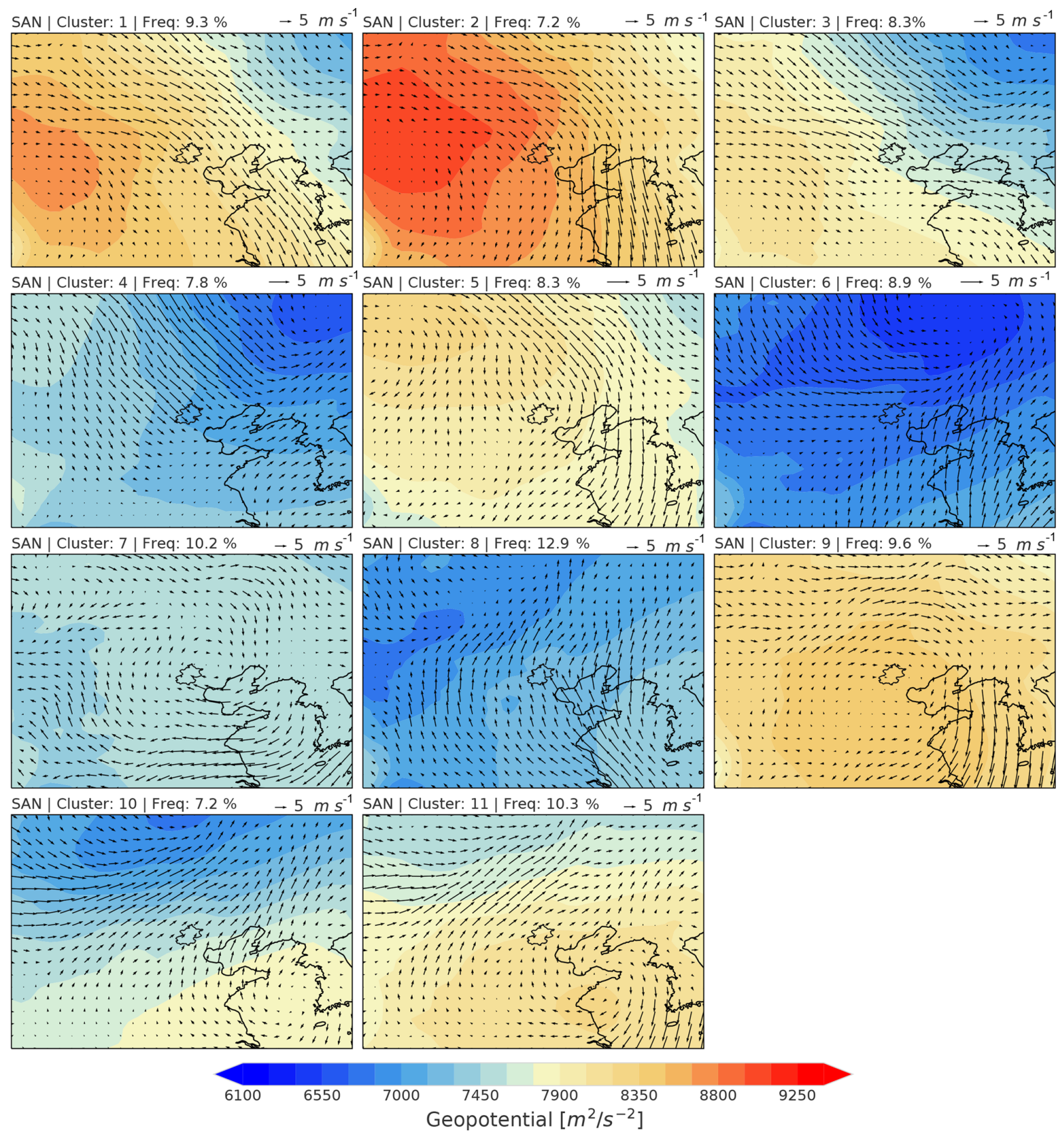

Figure 2. ERA-Interim (1988-2017) average $925 \mathrm{hPa}$ geopotential with $10 \mathrm{~m}$ horizontal wind vector for 11 circulation types classified for Beijing (municipal boundary; thin solid line) surroundings $\left(31-49^{\circ} \mathrm{N}, 103-129^{\circ} \mathrm{E}\right)$ determined with the SANDRA method (COST733 class software). Frequency of occurrence is given in the cluster caption. For a discussion of conditions associated with each CT, see Sect. 4.3.

North-westerly flow (over Beijing) is driven by high pressure in the west of the domain (Fig. 2). These are followed by CTs 5,3 and 7, occurring $14 \%, 7 \%$ and $4 \%$ of the time, respectively. CTs 3 and 5 are associated with relatively low pressure in the north-east (September-May period), while CT 7 has a south-easterly winds from the Bohai Sea. CTs 4, 6 and 8 did not occur during the winter campaign.
During the summer campaign (Fig. 3b), the most frequent CTs were 8, 7, 4 and $6(33 \%, 25 \%, 19 \%$ and $10 \%$ of the time, respectively). CTs 8 and 6 , which did not occur during the winter campaign period, are associated with the summer monsoon, advecting moist, warm air from the south and south-east (Fig. 2). While southerly and northerly flows converge over Beijing for CT 6, slightly weaker low pressure to the north-east means north-westerly flow dominates for CT 

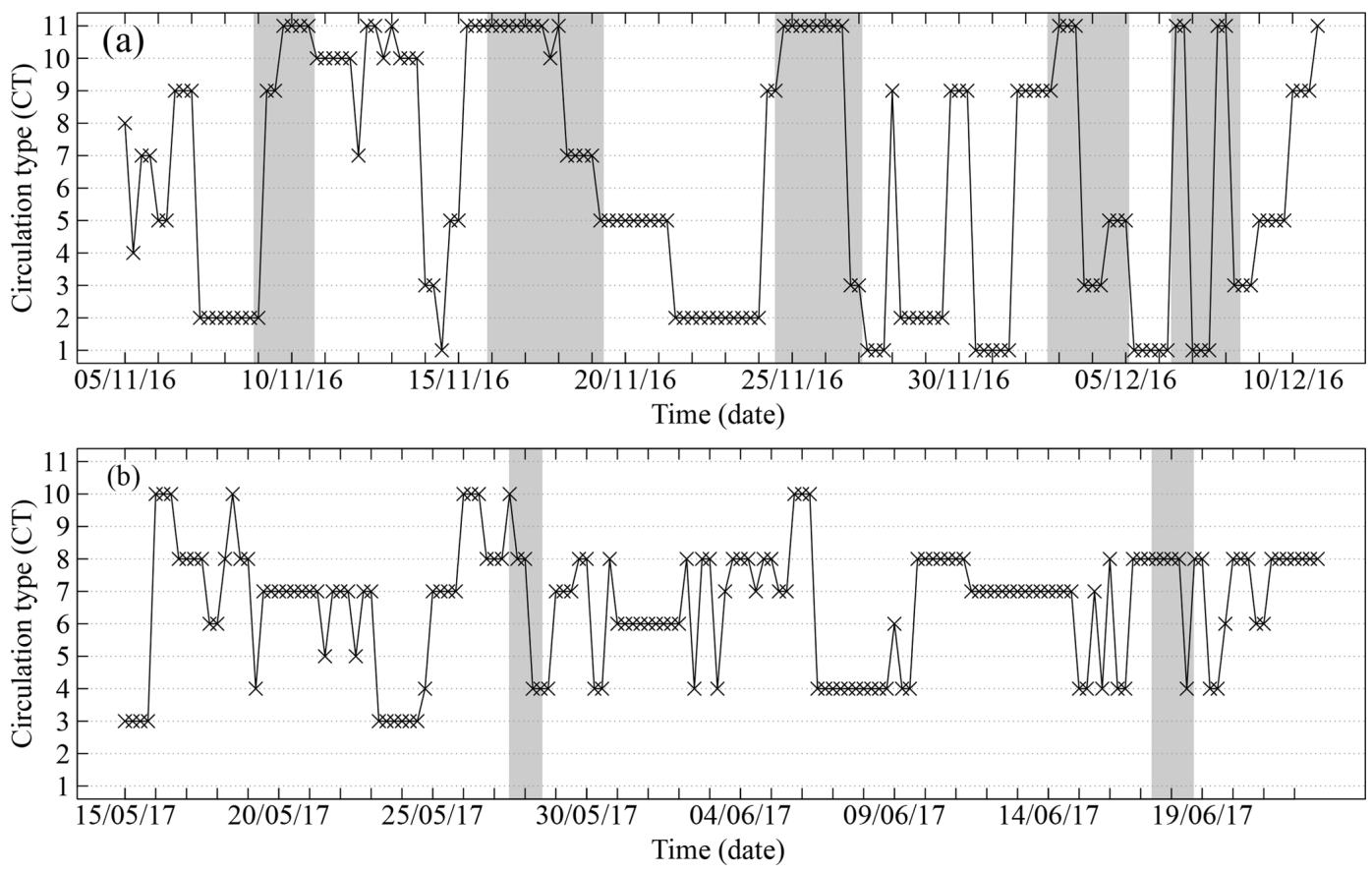

Figure 3. Time series of circulation types (CTs) during the two field campaigns: (a) winter and (b) summer. The 11 CTs are shown in Fig. 2; see text for an additional description. Shading shows the pollution events identified in Sect. 5 and Fig. 5.

4. High pressure to the west or south of Beijing is rare during the summer campaign, so that CTs $1,2,9$ and 11 do not occur, and CTs 3 and 5 are rather rare $(5 \%$ and $1 \%$, respectively).

\subsection{Meteorological conditions during the field campaigns}

To assess how local-scale flow related to ERA-Interim fields (Sect. 4.3) compared to local conditions, the link between the coarse gridded data and tower-based sonic anemometer observations is explored based on wind roses (Fig. 4). The 30-year climatology (Fig. 4a, d) confirms the clear seasonality in wind direction affecting the occurrence of CTs discussed (Sect. 4.3); i.e. during the winter intensive campaign period (10 November-10 December), north-easterly flow clearly dominates, while southerly wind directions are most common during the summer campaign period (20 May22 June). The wind roses for winter 2016 and summer 2017 (Fig. 4b, e) are slightly noisier but show similar tendencies to the climatology. The general large-scale patterns are consistent with the in situ wind measurements (Fig. 4c, f). However, a slight diversion towards northerly and south-westerly flow and lower wind speeds occurred in winter and summer (Fig. 4c and f), respectively, when compared to the largerscale data (Fig. 4b and d). In addition, south-westerly flows were more frequent in winter 2016 (Fig. 4b and c) than during the 30-year average climatology (Fig. 4a), which had
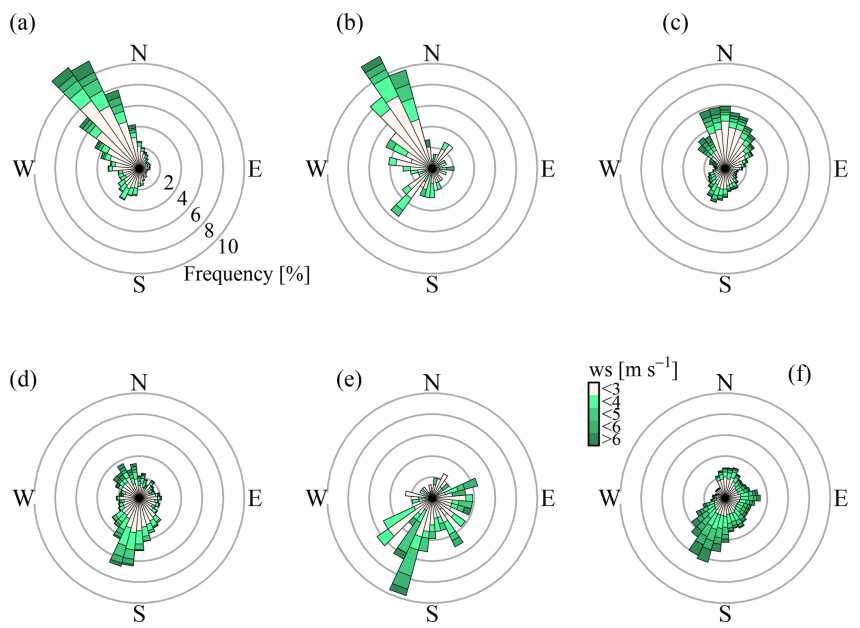

Figure 4. Beijing wind roses: (a, b, d, e) ERA-Interim $10 \mathrm{~m}$ horizontal wind $\left(40^{\circ} \mathrm{N}, 116.5^{\circ} \mathrm{E}\right)$ and $(\mathbf{c}, \mathbf{f})$ sonic anemometer (Table 1$)$ at IAP 320 m a.g.l. for (a) 5 November-10 December in 1988-2017, (d) 15 May-22 June in 1988-2017, (b, c) 5 November-10 December 2016 and (e, f) 15 May-22 June 2017.

the potential to bring more polluted air in the upwind Hebei province to the observation sites in Beijing.

At $102 \mathrm{~m}$, the flow is consistent with northerlies and northwesterlies in the winter campaign and dominantly southerly and easterlies during the summer campaign (Fig. S1 in the Supplement). The measured hourly mean wind speed, temperature and relative humidity were $3.1 \mathrm{~m} \mathrm{~s}^{-1}, 8.3^{\circ} \mathrm{C}$ and 
$43.8 \%$ in winter, and $3.6 \mathrm{~m} \mathrm{~s}^{-1}, 25^{\circ} \mathrm{C}$ and $46.7 \%$ in summer, respectively. Typical diurnal patterns were observed, with higher wind speed and temperature during the day and RH at night. During the winter haze events (defined in Fig. 5), wind speed at $102 \mathrm{~m}$ was low (an average of $1.8 \mathrm{~m} \mathrm{~s}^{-1}$ ) and mainly from the south-west direction (Fig. S1).

\section{Air quality during the field campaigns}

\subsection{Winter}

During the winter campaign, the daily average concentration of $\mathrm{PM}_{2.5}$ at IAP was $91.2 \mu \mathrm{g} \mathrm{m}^{-3}$ from the Partisol gravimetric measurements (Table 4) and $94.0 \mu \mathrm{g} \mathrm{m}^{-3}$ from an online FDMS (filter dynamic measurement system). The maximum hourly $\mathrm{PM}_{2.5}$ concentration was $438 \mu \mathrm{g} \mathrm{m}^{-3}$ (Fig. 5, which shows the haze events listed in Table 5). $\mathrm{PM}_{2.5}$ concentrations significantly exceeded both the daily air quality limit of China $\left(75 \mu \mathrm{g} \mathrm{m}^{-3}\right)$ and WHO $\left(25 \mu \mathrm{g} \mathrm{m}^{-3}\right)$. During the whole winter campaign period, nearly $50 \%$ of the hours had $\mathrm{PM}_{2.5}$ mass concentration higher than $75 \mu \mathrm{g} \mathrm{m}^{-3}$ (Fig. 5). The online $\mathrm{PM}_{10}$ concentration observed at the Olympic Park national air quality monitoring station was up to $560 \mu \mathrm{g} \mathrm{m}^{-3}$ during the campaign, with an average of $130.6 \mu \mathrm{g} \mathrm{m}^{-3}$. Average concentrations of $\mathrm{NO}_{2}, \mathrm{O}_{3}, \mathrm{SO}_{2}$ and $\mathrm{CO}$ were $69.7 \pm 33.3,16.4 \pm 17.0$ and $14.9 \pm 11.1 \mu \mathrm{g} \mathrm{m}^{-3}$ and $1.53 \pm 1.02 \mathrm{mg} \mathrm{m}^{-3}$, respectively (Table 4). Most of the criteria pollutants showed a similar temporal pattern (Fig. 5), except $\mathrm{O}_{3}$.

The daily average concentration of $\mathrm{PM}_{2.5}$ was $99.7 \mu \mathrm{g} \mathrm{m}{ }^{-3}$ at Pinggu (Table 4; based on Partisol gravimetric measurements). The maximum hourly $\mathrm{PM}_{2.5}$ concentration was $617 \mu \mathrm{g} \mathrm{m}^{-3}$ (Fig. 5). Similar to that at IAP, nearly $50 \%$ of the hours had $\mathrm{PM}_{2.5}$ mass concentrations greater than $75 \mu \mathrm{g} \mathrm{m}^{-3}$. Average concentrations of $\mathrm{NO}_{2}, \mathrm{O}_{3}, \mathrm{SO}_{2}$ and $\mathrm{CO}$ are $46.4 \pm 25.5,22.3 \pm 22.2$ and $15.4 \pm 6.7 \mu \mathrm{g} \mathrm{m}^{-3}$ and $1.47 \pm$ $1.17 \mathrm{mg} \mathrm{m}^{-3}$, respectively (Table 4). $\mathrm{PM}_{2.5}$ was slightly higher at the rural site but $\mathrm{NO}, \mathrm{CO}$ and $\mathrm{SO}_{2}$ were comparable between the two sites. $\mathrm{PM}_{2.5}$ and $\mathrm{O}_{3}$ each had similar temporal patterns at the urban and rural sites (Fig. 5), indicating a synoptic-scale meteorological impact. The larger difference in the temporal variation of $\mathrm{NO}, \mathrm{NO}_{2}$ and $\mathrm{SO}_{2}$ may reflect the varying contribution of more local sources. Large differences in temporal patterns of air pollutants were found on 4 December 2016 when $\mathrm{PM}_{2.5}, \mathrm{SO}_{2}$ and $\mathrm{NO}$ concentrations were much higher at Pinggu than at IAP.

Diurnal cycles of particles, $\mathrm{NO}_{2}$ and $\mathrm{CO}$ showed no distinct peak but an increment during the nighttime, suggesting the possible impact of boundary layer and/or anthropogenic emissions in winter (Fig. 6). The peak NO levels at 07:00 LT are likely caused by the morning rush hour road traffic. $\mathrm{PM}_{2.5}$ concentration increased sharply from 18:00 LT at Pinggu (not shown), suggesting important local emissions, likely domes- tic heating and cooking. $\mathrm{SO}_{2}$ and $\mathrm{O}_{3}$ had their highest levels mid-morning or at noon (Fig. 6).

Variations of particles, $\mathrm{NO}_{x}$ and $\mathrm{SO}_{2}$ show higher levels of these pollutants when air masses were from the south or south-west (Fig. S2), indicating it was impacted by regional transport. All pollutants, except $\mathrm{O}_{3}$, had higher mass concentrations when wind speeds were low, suggesting an influence from the local sources. The NO wind rose suggests a strong local source with little contribution from long-range transport. The $\mathrm{O}_{3}$ concentration was higher during northerlies and when the concentrations of other pollutants such as $\mathrm{NO}_{x}$ and $\mathrm{PM}_{2.5}$ were lower (Fig. S2).

SNAQ box measurements at six levels ( 8 to $320 \mathrm{~m}$ ) during the winter campaign (Fig. 7) have similar overall temporal patterns of $\mathrm{CO}$ and $\mathrm{NO}$ to that measured by standard gas analyser (Fig. 5). In most cases, the air pollutant levels are similar at different levels of the tower. There are notable differences in $\mathrm{NO}, \mathrm{CO}$ and $\mathrm{CO}_{2}$ on 11, 12 and 16-17 November, which suggests that the mixed layer height was low (e.g. $<150 \mathrm{~m})$. Interestingly, the $\mathrm{O}_{\mathrm{x}}\left(\mathrm{NO}_{2}+\mathrm{O}_{3}\right)$ levels are relatively homogeneous across the different levels. These measurements have implications on the role atmospheric chemistry play in transformation of species in the boundary layer, and the measurements also provide useful information that confirms mixed layer height determinations from independent methods such as the ceilometer (Table 1).

According to the meteorological standards (QX/T1132010), haze is defined as (i) visibility $<10 \mathrm{~km}$ at relative humidity $(\mathrm{RH})<80 \%$ or (ii) if RH is between 80 and $95 \%$, visibility $<10 \mathrm{~km}$ and $\mathrm{PM}_{2.5}>75 \mu \mathrm{g} \mathrm{m}^{-3}$. During the winter campaign, 640 of the $1633 \mathrm{~h}$ were classified as haze periods using visibility data from Beijing Capital Airport (Fig. S3); within the haze hours, $75 \%$ had $\mathrm{PM}_{2.5}$ greater than $75 \mu \mathrm{g} \mathrm{m}^{-3}$ (Area A; Fig. S3) and the rest had a visibility less than $10 \mathrm{~km}$ but with a RH $<80 \%$ (Area B; Fig. S3).

Characteristics of five major haze events during the winter campaign (Fig. 5) show that $\mathrm{PM}_{2.5}, \mathrm{NO}_{2}, \mathrm{SO}_{2}$ and $\mathrm{CO}$ had similar trends but $\mathrm{O}_{3}$ levels dropped to very low concentration $(<2 \mathrm{ppb})$. The events are defined in Table 5.

\subsection{Summer}

Concentrations of air pollutants excluding ozone during the summer campaign were much lower than in winter (Fig. 8, Table 4). Average daily concentration of $\mathrm{PM}_{2.5}$ and $\mathrm{PM}_{10}$ at IAP were $31.4 \pm 14.7$ and $74.9 \pm 29.3 \mu \mathrm{g} \mathrm{m}^{-3}$ (based on the gravimetric method), respectively. These levels were slightly higher than those at Pinggu (27.8 \pm 13.3 and $62.9 \pm 29.3 \mu \mathrm{g} \mathrm{m}^{-3}$ ). Concentrations of ozone were $4-5$ times higher during the summer campaigns $\left(106.9 \pm 71.6 \mu \mathrm{g} \mathrm{m}^{-3}\right.$ at IAP and $91.8 \pm 62.7 \mu \mathrm{g} \mathrm{m}^{-3}$ at Pinggu) than in the winter campaign. Average concentrations of $\mathrm{NO}_{2}, \mathrm{SO}_{2}$ and $\mathrm{CO}$ were $41.3 \pm 23.5,6.3 \pm 6.8 \mathrm{\mu g} \mathrm{m}^{-3}$ and $0.61 \pm 0.32 \mathrm{mg} \mathrm{m}^{-3}$ at IAP, respectively (Table 4). The concentrations of $\mathrm{NO}_{2}$ and $\mathrm{CO}$ were lower at Pinggu, while that of $\mathrm{SO}_{2}$ was similar. All 


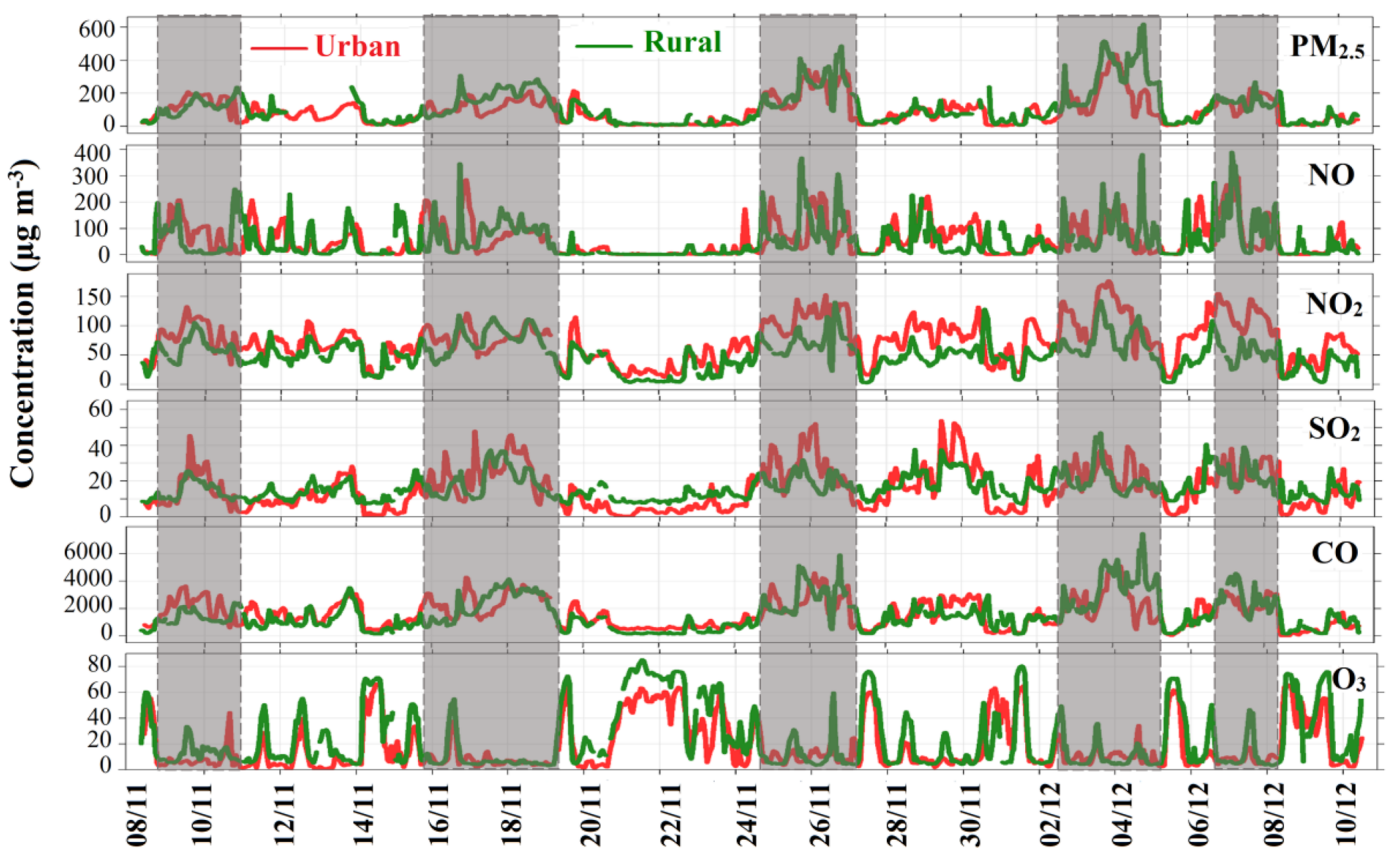

Figure 5. Time series of air quality variables at the urban and rural sites during the winter campaign. Five haze events are indicated (shading; see also Table 4).

Table 4. Average air quality variables at IAP, Pinggu and 12 national monitoring sites $(12 \mathrm{~N})$ during the field campaigns (10 November11 December 2016; and 21 May-22 June 2017). The 12 national sites 5-year mean concentrations for same times of the years (12N-5Y) and for the same time of the year (campaign period) (12N-campaign) are shown. Data are mean \pm SD (range of daily mean concentration).

\begin{tabular}{|c|c|c|c|c|c|c|c|c|}
\hline Pollutant ${ }^{\mathrm{a}}$ & \multicolumn{4}{|c|}{ Winter (10 November-11 December 2016) } & \multicolumn{4}{|c|}{ Summer (21 May-22 June 2017) } \\
\hline $\mathrm{PM}_{2.5}^{\mathrm{b}}$ & $\begin{array}{r}91.2 \pm 63.7 \\
(10.3-239.9)\end{array}$ & $\begin{array}{r}99.7 \pm 77.8 \\
(13.3-294.3)\end{array}$ & $\begin{array}{r}84.01 \pm 89.1 \\
(3.2-593.3)\end{array}$ & $\begin{array}{l}95.3 \pm 79.6 \\
(4.7-408.8)\end{array}$ & $\begin{array}{l}31.4 \pm 14.7 \\
(12.2-78.8)\end{array}$ & $\begin{array}{l}27.8 \pm 13.3 \\
(10.6-70.3)\end{array}$ & $\begin{array}{l}58.7 \pm 40.0 \\
(4.2-250.3)\end{array}$ & $\begin{array}{l}41.7 \pm 22.3 \\
(8.9-134.1)\end{array}$ \\
\hline $\mathrm{PM}_{10}^{\mathrm{b}}$ & $\begin{array}{l}130.6 \pm 87.0 \\
(20.0-329.2)\end{array}$ & $\begin{array}{l}121.9 \pm 80.4 \\
(10.4-312.1)\end{array}$ & $\begin{array}{r}112.8 \pm 102.2 \\
(5-662.0)\end{array}$ & $\begin{array}{r}134.5 \pm 100.4 \\
(6.0-550.1)\end{array}$ & $\begin{array}{r}74.9 \pm 29.3 \\
(22.5-164.6)\end{array}$ & $\begin{array}{r}62.9 \pm 29.3 \\
(15.1-141.9)\end{array}$ & $\begin{array}{l}94.6 \pm 52.7 \\
(5.0-463.2)\end{array}$ & $\begin{array}{l}81.9 \pm 37.1 \\
(6.0-277.8)\end{array}$ \\
\hline $\mathrm{SO}_{2}$ & $\begin{array}{r}14.9 \pm 11.1 \\
(0.1-50.8)\end{array}$ & $\begin{array}{l}15.4 \pm 6.7 \\
(6.2-44.4)\end{array}$ & $\begin{array}{l}16.6 \pm 16.2 \\
(1.4-112.0)\end{array}$ & $\begin{array}{l}14.2 \pm 9.4 \\
(2.1-51.4)\end{array}$ & $\begin{array}{r}6.3 \pm 6.8 \\
(0.1-38.2)\end{array}$ & $\begin{array}{r}8.9 \pm 4.7 \\
(4.2-41.2)\end{array}$ & $\begin{array}{r}10.1 \pm 10.6 \\
(1.8-82.3)\end{array}$ & $\begin{array}{r}7.4 \pm 6.6 \\
(1.8-64.5)\end{array}$ \\
\hline $\mathrm{CO}$ & $\begin{array}{r}1.53 \pm 1.02 \\
(0.7-5.0)\end{array}$ & $\begin{array}{r}1.47 \pm 1.17 \\
(0.1-6.9)\end{array}$ & $\begin{array}{r}1.65 \pm 1.38 \\
(0.1-9.6)\end{array}$ & $\begin{array}{r}1.86 \pm 1.17 \\
(0.3-5.7)\end{array}$ & $\begin{array}{r}0.61 \pm 0.32 \\
(0.1-2.5)\end{array}$ & $\begin{array}{r}0.52 \pm 0.29 \\
(0.1-2.3)\end{array}$ & $\begin{array}{r}0.93 \pm 0.74 \\
(0.2-8.7)\end{array}$ & $\begin{array}{r}0.74 \pm 0.33 \\
(0.2-2.5)\end{array}$ \\
\hline
\end{tabular}

${ }^{\mathrm{a}}$ Units: $\mu \mathrm{g} \mathrm{m}^{-3}$, except $\mathrm{CO}$ units: $\mathrm{mg} \mathrm{m}^{-3}$. ${ }^{\mathrm{b}} \mathrm{PM}_{2.5}$ and $\mathrm{PM}_{10}$ from IAP and Pinggu measured by a gravimetric method; all other data are online hourly mean measurements.

pollutants except $\mathrm{PM}_{2.5}$ show more or less different temporal patterns (Fig. 8), suggesting differences in sources at Pinggu and IAP during the summer campaign.

Diurnal patterns of $\mathrm{NO}, \mathrm{NO}_{2}$ and $\mathrm{CO}$ at IAP showed a distinct peak in the early morning, suggesting the contribution of traffic emissions (Fig. 6). $\mathrm{O}_{3}$ and $\mathrm{O}_{x}$ concentration peaked mid-afternoon. The IAP $\mathrm{PM}_{2.5}$ pollution rose sug- gests that both local and regional sources (from the south and south-east directions) impact the site (Fig. S2). Unlike winter, high ozone concentrations occur during southerlies to south-westerlies, suggesting a regional source of this pollutant. $\mathrm{NO}$ and $\mathrm{NO}_{x}$ were largely from local sources during the summer campaign. 
Table 5. Haze periods during the summer and winter campaign periods.

\begin{tabular}{llll}
\hline Event & Time $(\mathrm{LT})$ & $\mathrm{PM}_{2.5}\left(\mu \mathrm{g} \mathrm{m}^{-3}\right)$ & Visibility $(\mathrm{km})$ \\
\hline Winter haze event 1 & $11 / 08$ 21:00-11/10 16:00 & $158(79-229)$ & $4.1(2.3-8)$ \\
Winter haze event 2 & $11 / 1521: 00-11 / 1908: 00$ & $143(56-244)$ & $4.2(0.6-8)$ \\
Winter haze event 3 & $11 / 2412: 00-11 / 2702: 00$ & $210(68-363)$ & $4.2(1.5-8)$ \\
Winter haze event 4 & $12 / 0216: 00-12 / 0502: 00$ & $239(58-530)$ & $3.9(0.9-8)$ \\
Winter haze event 5 & $12 / 0609: 00-12 / 0810: 00$ & $144(64-229)$ & $4.6(2.2-8)$ \\
Summer haze event 1 & 27/05 12:00-28/05 13:00 & $107(62-163)$ & $6.8(4.5-9)$ \\
Summer haze event 2 & $17 / 0609: 00-18 / 0617: 00$ & $90.5(60-153.3)$ & $9.3(7-13)$ \\
\hline
\end{tabular}

Note: data in parentheses show the hourly range.
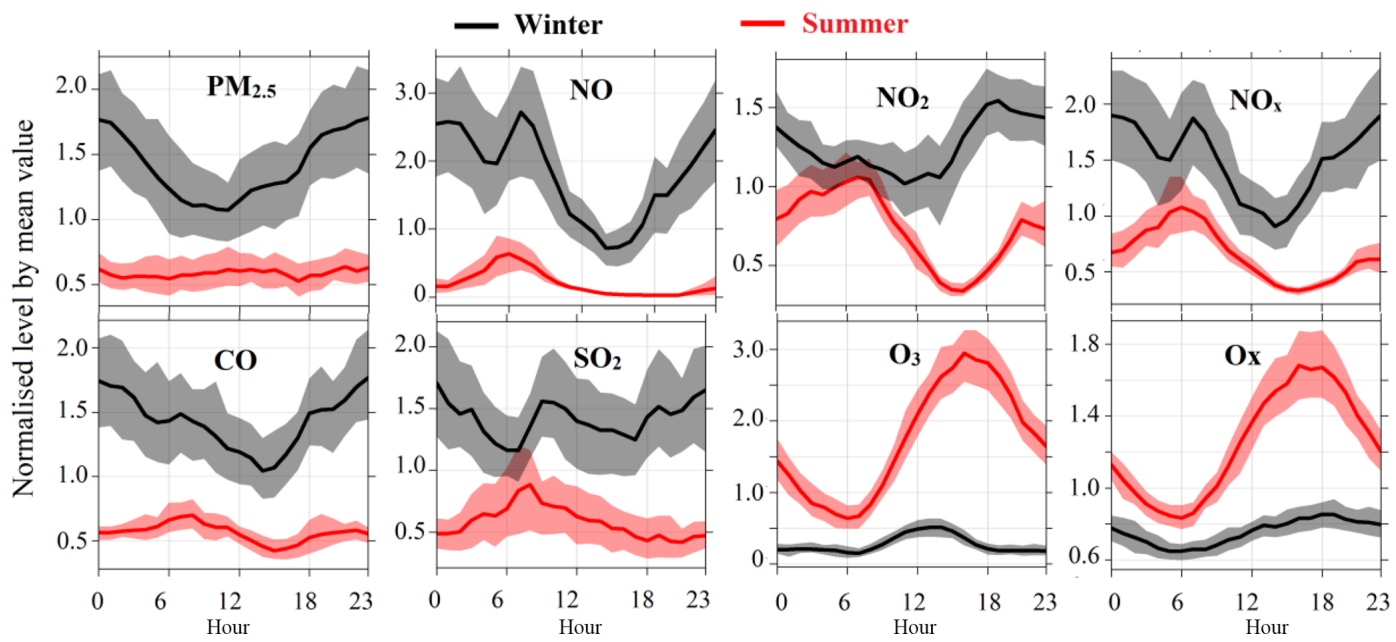

Figure 6. Diurnal patterns of gaseous pollutants normalised by average concentrations at IAP during winter and summer campaigns. The line shows the mean concentrations and shaded area as $95 \%$ confidence interval in the difference in mean concentrations.

Characteristics of two minor haze events (IAP) during the summer campaign (Fig. 8) are shown in Table 5.

\subsection{Air quality in the wider Beijing megacity during the field campaigns}

To assess if the IAP air quality is broadly representative of the wider Beijing megacity, air quality parameters at the 12 national air quality stations were correlated with each other (Fig. 9). A high correlation is observed with $\mathrm{PM}_{2.5}$ across all sites except the rural background air quality station at Ming Tombs (G2; Fig. 1); $\mathrm{PM}_{10}, \mathrm{CO}$ and $\mathrm{NO}_{2}$ at the urban sites are highly correlated but not with the rural and suburban sites (G2, G9 and G10; Fig. 1), suggesting a more local source for these pollutants, comparing to $\mathrm{PM}_{2.5}$ and $\mathrm{O}_{3} ; \mathrm{SO}_{2}$ between sites shows a lower correlation compared to all other pollutants. The particularly high spatial correlations of both $\mathrm{PM}_{2.5}$ and $\mathrm{O}_{3}$ across almost all sites indicate a regional pollution phenomenon for the two pollutants. These results suggest that the air quality at the IAP urban site was broadly consistent with that at the other urban sites.

In general, $\mathrm{PM}_{2.5}$ mass concentrations are similar at all the urban sites including IAP which are higher than at the subur- ban and rural background national monitoring sites (G2, G9 and G10; Fig. S4). The Pinggu site has relatively high $\mathrm{PM}_{2.5}$ pollution during the winter campaign but has the lowest concentrations during the summer campaign. This suggests that local anthropogenic sources have a major impact on $\mathrm{PM}_{2.5}$ at this site during the winter campaign. Source apportionment results, notably high-time-resolution data, are being used to explore this.

The $\mathrm{PM}_{2.5}$ concentrations measured at IAP are highly correlated with those at the nearby national air quality station (Olympic Park or Aoti Zhongxin; see Fig. 1) (Fig. S5), which gives confidence that national air quality stations are of sufficient quality to provide valuable information on the spatial and temporal variation of key pollutants to supplement campaign measurements.

Table 4 shows that the IAP concentration data for all air quality variables are very close to the 5-year mean of the 12 national air quality monitoring stations. This lends further confidence that the chosen urban site represented well the overall pollution levels in the Beijing urban area. 


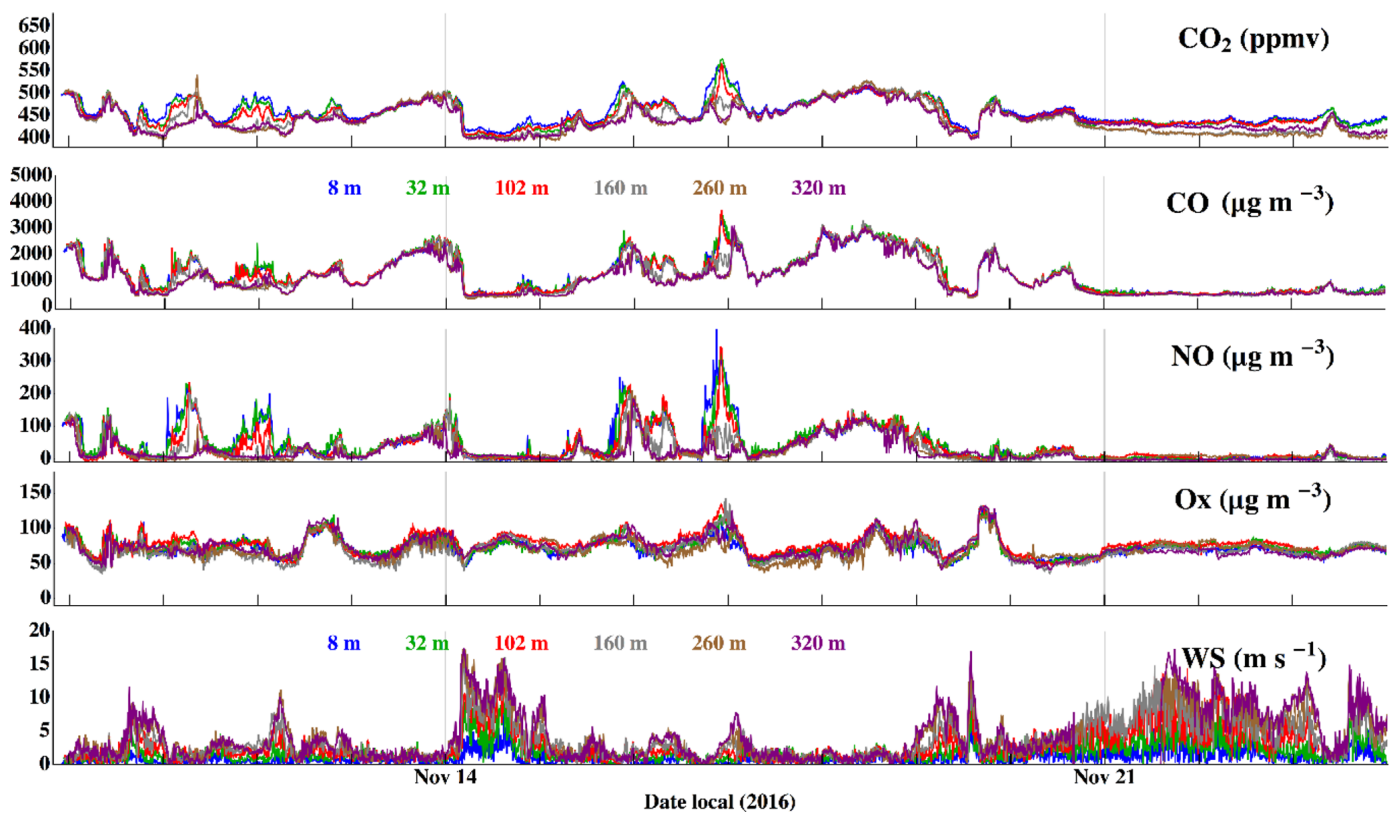

Figure 7. Time series of $\mathrm{CO}_{2}, \mathrm{CO}, \mathrm{NO}, \mathrm{O}_{x}\left(\mathrm{NO}_{2}+\mathrm{O}_{3}\right)$ and wind speed at six heights (colour) measured with SNAQ boxes on the IAP tower during the winter intensive field campaign.

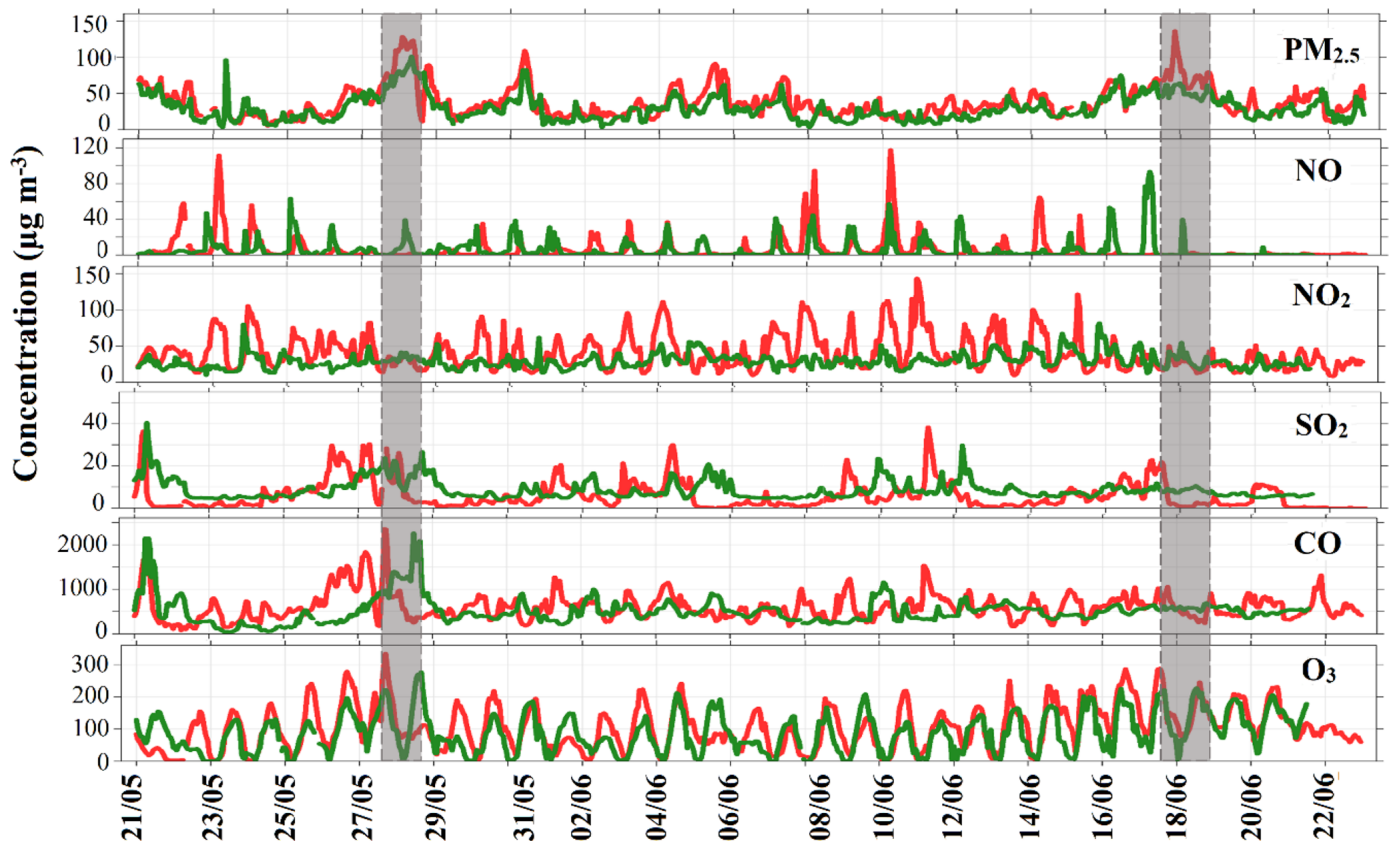

Figure 8. Time series of air quality variables at the urban and rural sites during the summer campaign. Two minor haze events are indicated (shading).

\subsection{Synoptic circulation and air quality}

The average mixed layer height observed at IAP varies with season and CT type (Fig. 10a). Lower mixed layer height is usually linked to air pollution events. The 11 CTs (Sect. 4.3) are clearly associated with distinct air quality conditions based on analysis of hourly air quality data for 2013-2017 at one of the national urban air quality stations (G11, Olympic Park; Fig. 1). Relatively low wind speeds of CT 7 may contribute to the long haze event from 15 to 19 November 2016 (Fig. 5). Most haze events during the winter campaign are cleared out by fresh air masses being advected from the north in CTs 3 or 5 (Fig. 3), which is also marked by the increase 

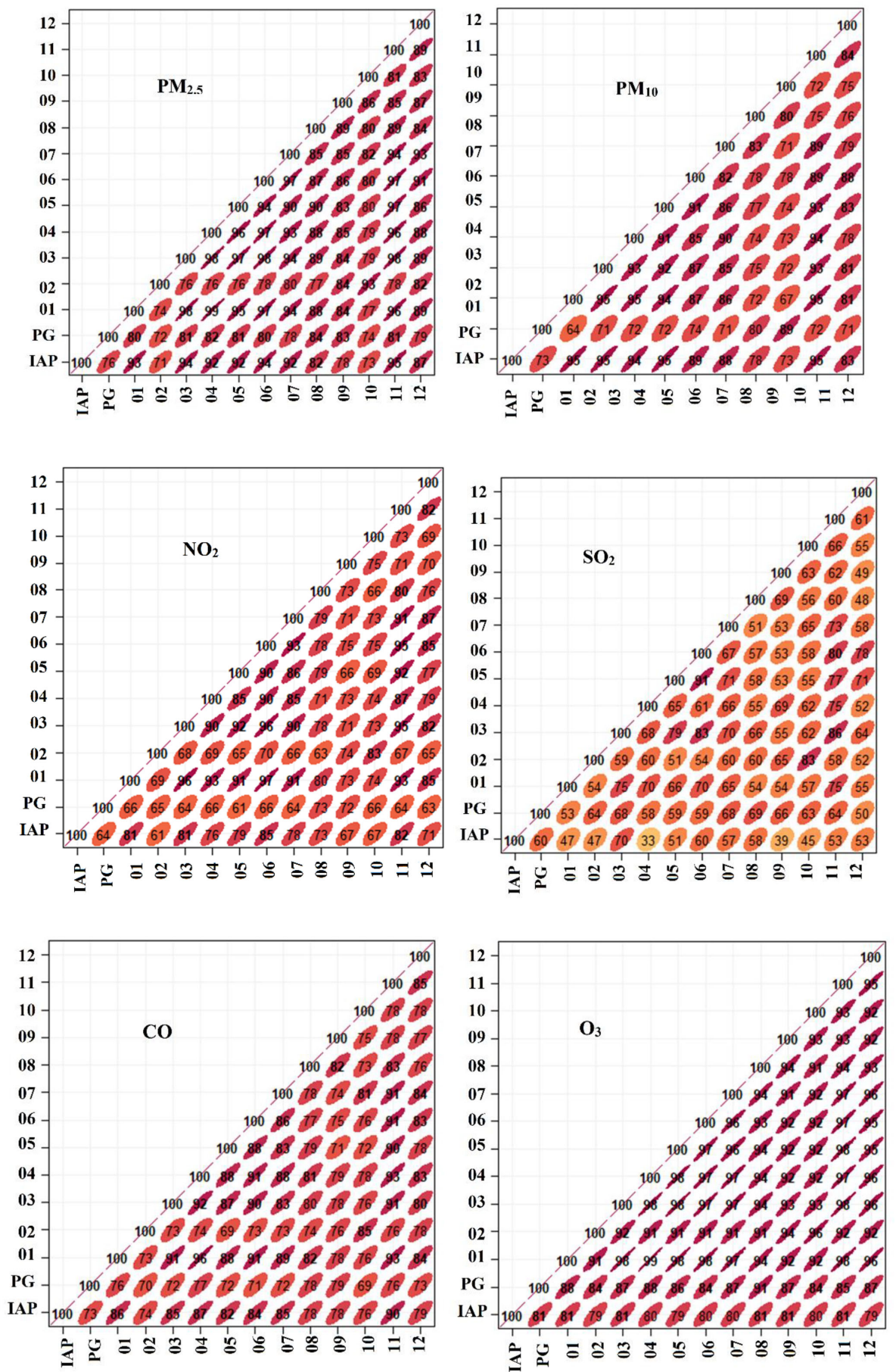

Figure 9. Correlations between the air quality at IAP, PQ and 12 monitoring station around Beijing. Stations G1-G12 (Fig. 1b) are labelled 01-12; PG is Pinggu.

in wind speed observed (Fig. S1). Relatively lower $\mathrm{PM}_{2.5}$ concentrations occurred (Fig. 10b) under NE flow conditions (CTs 1-5) and higher concentrations during southerly flow (CTs 6-8, 10). The highest $\mathrm{PM}_{2.5}$ concentrations occur during the heating season when regional flow showed stagnation (CTs 9, 11). All haze events during the winter campaign
(Figs. 3 and 5) are dominated by those CTs, although CTs with NE flow conditions occurred for short periods within the haze events (e.g. 18 November 2016, 4 December 2016). Ozone levels are highest during CTs 5-8 (Fig. 10c), which predominate during spring and summer (Fig. 10d). 

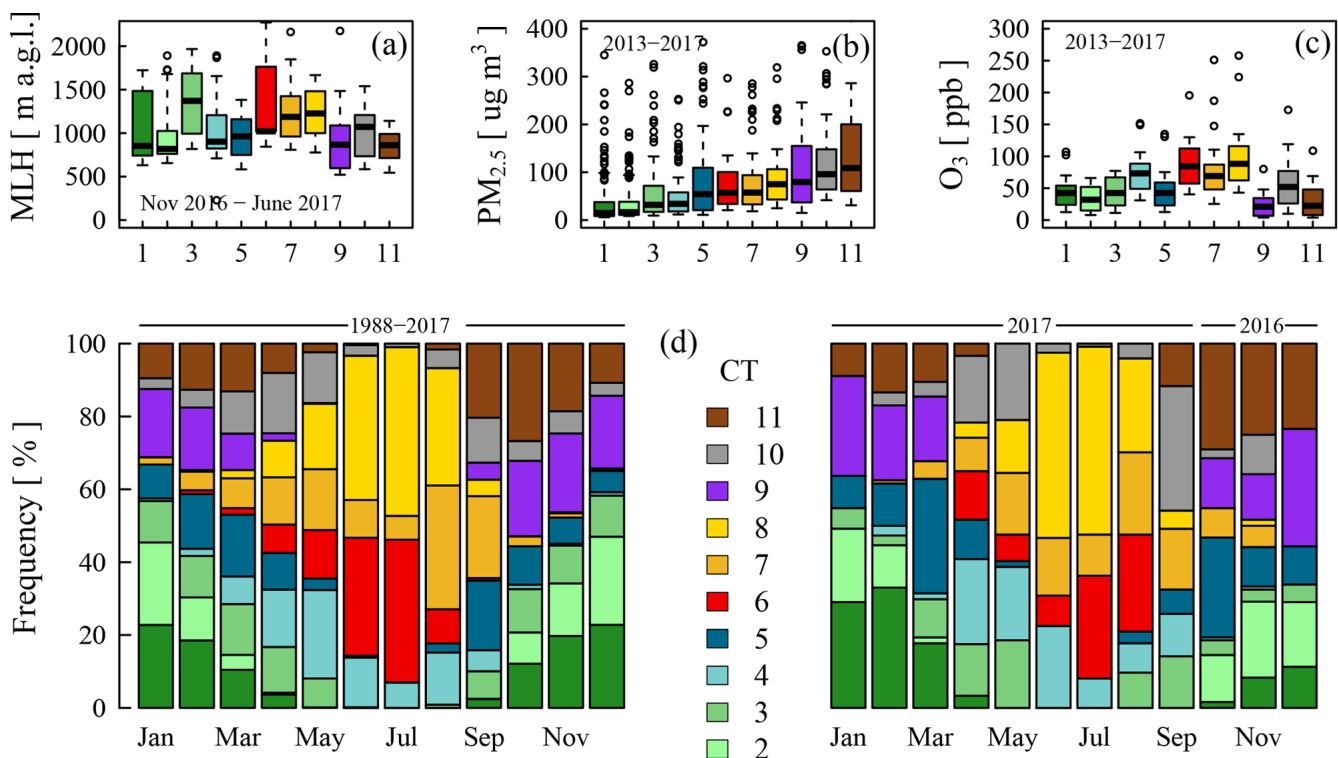

(d)
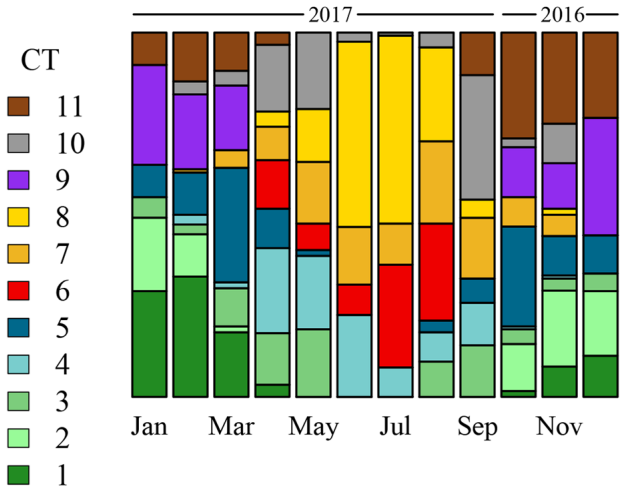

(e)
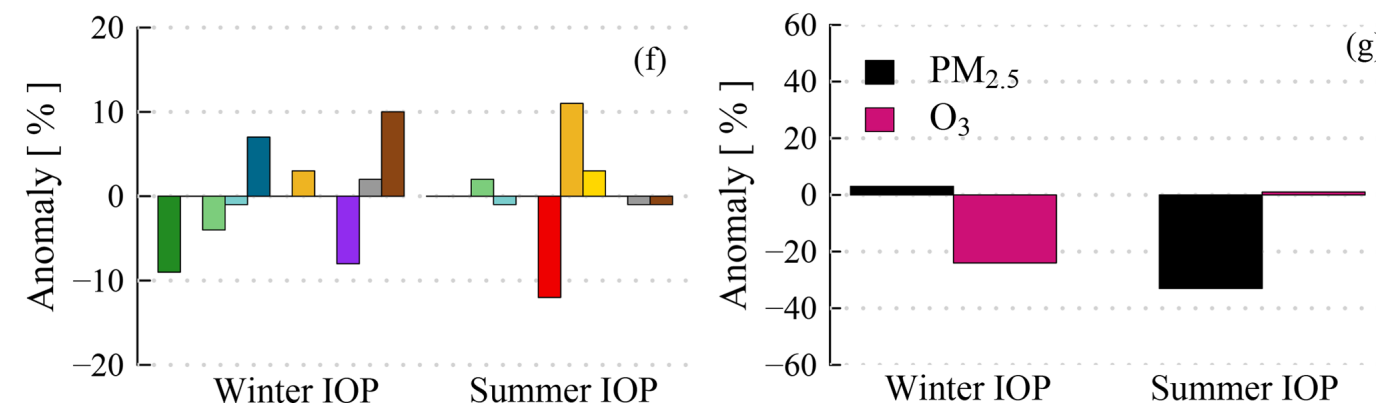

(g)

Figure 10. Analysis by circulation type (CT; Sect. 4.3) of (a) daily maximum mixed layer height (MLH) determined from ALC observations at IAP between November 2016 and June 2017 (analysis method; Kotthaus and Grimmond, 2018b); concentration of (b) $\mathrm{PM}_{2.5}$ and (c) $\mathrm{O}_{3}$ at the Olympic Park (i.e. Aoti Zhongxin, Fig. 1) in 2013-2017 from the national air quality network for different CTs; occurrence of CTs in (d) 1988-2017 and (e) October 2016-September 2017; (f) anomaly of CT frequency during the campaigns compared to 5-year (2013-2017) averages; and (g) anomaly of $\mathrm{PM}_{2.5}$ and $\mathrm{O}_{3}$ during the campaigns compared to 5-year (2013-2017) averages. IOP is the intensive observation period (i.e. campaign period).

In the October 2016-September 2017 period (Fig. 10e), the relative frequency of CTs differs slightly from the longterm climatology (Fig. 10d). During the winter campaign, clean air advection from the NE (CTs 1-3) was less frequent than in the 30-year climatology. Given synoptic circulation types associated with stagnation do have a similar occurrence during the winter campaign compared to the same time period within the previous 5 years (with CT 9 being $8 \%$ less frequent and CTs 10 and 11 being $2 \%$ and $10 \%$ more frequent; Fig. 10f), $\mathrm{PM}_{2.5}$ concentrations were similar to the 5 -year mean (Fig. 10g, winter campaign period compared to the same dates during 2013-2017). During the summer campaign, south-north contrasts in geopotential were apparently reduced, so CT 6 was $12 \%$ less frequent, while CT 7 was $11 \%$ more frequent (Fig. 10f). The reduced advection of particles from southerly directions might have contributed to a $33 \%$ lower $\mathrm{PM}_{2.5}$ concentrations compared to the 5-year average for the same time of year (Fig. $10 \mathrm{~g}$ ). The relative decrease in $\mathrm{O}_{3}$ (Fig. 10g) during the winter campaign (24\%) might be explained by cloud cover differences, which is being investigated.

\subsection{Summary of air quality during the campaigns}

In summary, the winter campaign was characterised by several high $\mathrm{PM}_{2.5}$ pollution events, with peak hourly concentrations ranging up to $617 \mu \mathrm{g} \mathrm{m}^{-3}$ (at Pinggu), whereas the summer experienced events of high ozone concentrations with the highest hourly average of $335 \mu \mathrm{g} \mathrm{m}^{-3}$ (at IAP). Air quality was generally poor during the winter campaign, with an average $\mathrm{PM}_{2.5}$ concentration of $91 \mu \mathrm{g} \mathrm{m}{ }^{-3}$ in urban Beijing but less severe than in the same period in 2015. Synoptic-scale meteorological analysis suggests that 


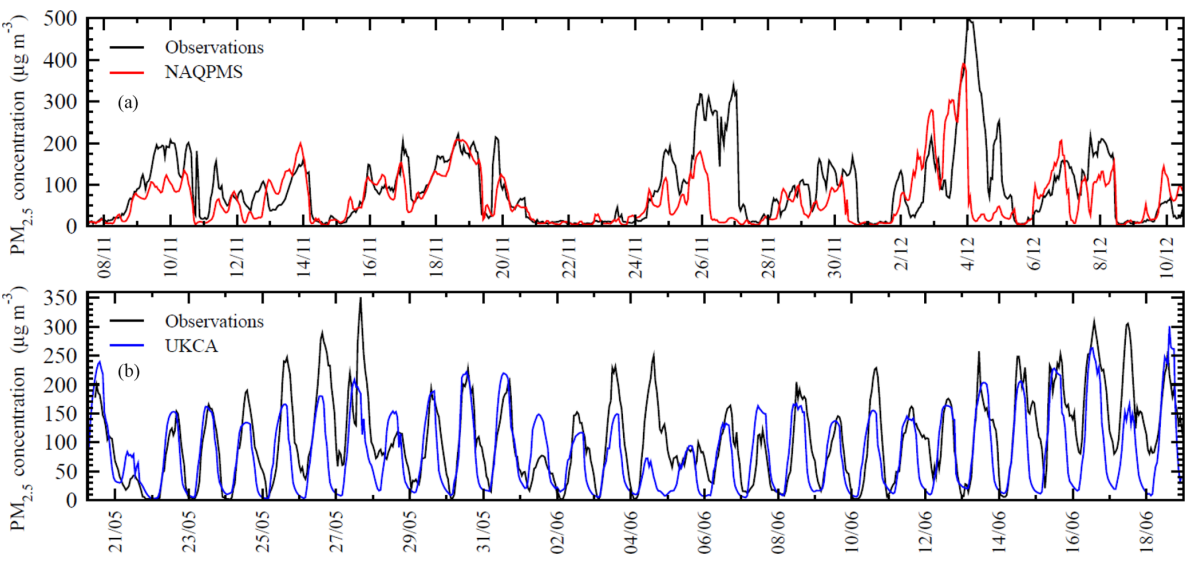

Figure 11. Comparison of observed (at IAP) and modelled pollutant concentrations showing (a) $\mathrm{PM}_{2.5}$ concentrations during the winter campaign compared with NAQPMS simulations and (b) $\mathrm{O}_{3}$ mixing ratios in summer compared with UKCA simulations.

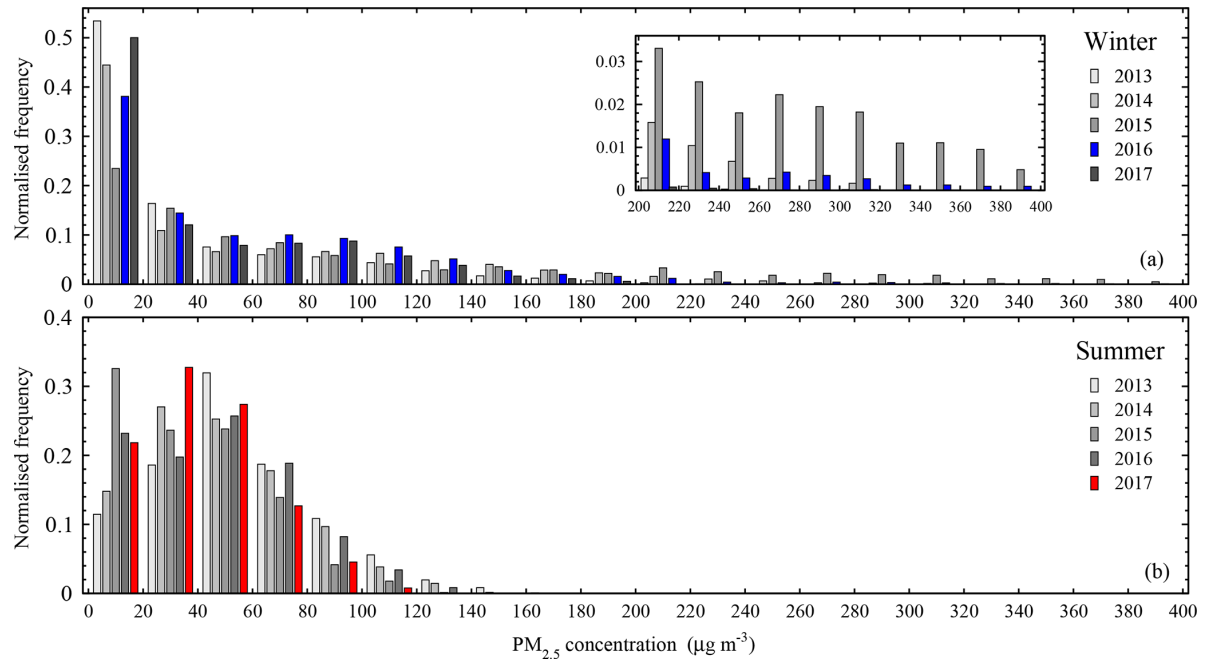

Figure 12. Frequency distribution of $\mathrm{PM}_{2.5}$ in Beijing over the winter (a) and summer (b) campaign periods from the NAQPMS model compared with those from the same periods over the past 5 years under the same emission conditions.

the greater stagnation and weak southerly circulation in November/December 2016 contributed to the poor air quality during all haze events detected, and overall the $\mathrm{PM}_{2.5}$ pollution level was similar to the 5-year average (20132017). $\mathrm{PM}_{2.5}$ levels were relatively low during the summer campaign, with the highest daily concentration of only $79 \mu \mathrm{g} \mathrm{m}^{-3}$, matching the cleanest periods over the previous 5 years.

\section{Preliminary air quality modelling and pollution climatology of the campaign periods}

Air quality modelling is a key component of the APHHBeijing programme. A range of models have been applied that span global (UKCA, GEOS-Chem), regional (WRF-Chem, CMAQ, NAQPMS) and urban to street scales (ADMS). This section provides an example of the compar- ison between model-simulated pollutant concentrations and APHH-Beijing observations made at IAP to demonstrate model capabilities. Results from specific modelling studies will be published separately.

Figure 11a shows that the magnitude and variation of wintertime $\mathrm{PM}_{2.5}$ concentrations are reasonably reproduced by NAQPMS during the winter campaign, although there is some weakness in capturing the highest $\mathrm{PM}_{2.5}$ levels during the haze events at the end of November and start of December. This is partly due to the representation of local meteorological features during this period, which bring these episodes to an end $6-12 \mathrm{~h}$ early. The diurnal variations in $\mathrm{O}_{3}$ during the summertime are reproduced relatively well by UKCA, which captures the rapid daytime formation of $\mathrm{O}_{3}$ and strong nighttime removal (Fig. 11b). The highest levels of daytime $\mathrm{O}_{3}$ are underestimated with the model, particularly during the episode at the end of May. However, there is 
a strong local contribution to this, as evident from the lower concentrations measured at Pinggu (Fig. 8), and these local differences are not fully resolved with the model. Despite this, the day-on-day build-up of daytime $\mathrm{O}_{3}$ during the periods of 22-27 May and 11-16 June is captured and demonstrates that the model reproduces the synoptic drivers of local $\mathrm{O}_{3}$ formation well.

We also investigated how representative the campaign periods were of the selected seasons in Beijing by comparing pollutant levels with those from the same period each year over the 2013-2017 period. The NAQPMS model was run for the full 5-year period driven by NCEP meteorology and using temporally varying emissions for a single year that is broadly representative of 2013 conditions. The same emissions were used each year so that the meteorological contribution to pollutant levels could be assessed. This provides important information that cannot be obtained from the monitoring data (as emission varies year by year). The frequency distribution of $\mathrm{PM}_{2.5}$ over each campaign period for each year is shown in Fig. 12. Winter 2016 was broadly typical of the 5-year period, with similar characteristics to winter 2014, but both years show higher $\mathrm{PM}_{2.5}$ under the same emissions than in 2013 or 2017. In addition, winter 2015 had substantially less favourable conditions for air quality, and more stagnant conditions led to three extended pollution episodes over the period with $\mathrm{PM}_{2.5}$ exceeding $200 \mu \mathrm{g} \mathrm{m}^{-3}$. In contrast, the summer period in 2017 was cleaner than average, with $\mathrm{PM}_{2.5}$ levels very similar to 2015, and about $25 \%$ less than in 2013, 2014 or 2016 . These results are broadly consistent with those based on synoptic weather analyses (Sect. 5.4) as well as by Vu et al. (2019).

\section{Summary}

APHH-Beijing is an integrated and multidisciplinary research programme conducted by leading UK and Chinese researchers to (1) quantify sources and emissions of urban atmospheric pollutants; (2) elucidate processes affecting urban atmospheric pollution events; (3) estimate the personal exposure and impacts of air pollution on human health and (4) develop intervention strategies to improve air quality and reduce health impacts in the Beijing megacity. This introduction paper outlines the motivation of the APHH-Beijing programme and provides the background air quality and meteorological conditions during the two intensive field campaigns that form the basis of data interpretation for campaign observations.

APHH-Beijing has measured the fluxes of key air pollutants, including $\mathrm{NO}_{x}, \mathrm{CO}, \mathrm{BC}$, VOCs and speciated particulate matter, applied a suite of traditional and modern techniques to apportion the sources of particulate matter, determined a wide range of pulmonary and cardiovascular biomarkers linking to direct personal exposure and extensive fixed-station monitoring as well as source apportionment re- sults and has evaluated the effectiveness of Beijing's air pollution control policies using both chemical transport models and novel machine learning techniques. A number of papers have already been published by the APHH-Beijing programme including those in this special issue (J. Wang et al., 2019; Pan et al., 2019; Xia et al., 2018; Zhou et al., 2018; H. Wang et al., 2018; Lyu et al., 2019; Hollaway et al., 2019; Du et al., 2018; Liu et al., 2019, 2018; Smith et al., 2019; Vu et al., 2019; El zein et al., 2019). More papers are being prepared for publication in this special issue and elsewhere, which will cover (but are not limited to) emission fluxes of air pollutants, chemical composition and source apportionment of fine particles, satellite observations of trace gases and aerosols, sources and processes leading to haze events and photochemical smogs, physical and optical properties of aerosol particles, formation processes of secondary aerosols, urban meteorology, feedbacks between haze, photochemistry and meteorology, integrated regional and urban scale modelling, personal exposure to air pollutants and human health effects of air pollution.

Data availability. Data are available at http://catalogue.ceda. ac.uk/uuid/7ed9d8a288814b8b85433b0d3fec0300 (last access: 20 May 2019).

Supplement. The supplement related to this article is available online at: https://doi.org/10.5194/acp-19-7519-2019-supplement.

Author contributions. ZS drafted the manuscript and is the science coordinator of the APHH-Beijing programme. RMH, KBH, ACL, PQF, TZ, FJK, ML, ZWS, DBG and ST are the lead PIs of the five research projects who led the funding applications and the research. They also drafted Sect. 2. TV plotted many of graphs and carried out the data analysis. SK, SG and MD carried out analysis and wrote Sects. 4.3 and 5.4; and YLW, MH, ZFW and OW carried out modelling and plotted Figs. 11 and 12. PFQ, JL and ZT led the air quality measurements at the two measurement sites. SY, JL, RED, LR, DL, JA, DB, WJ, LC, LC, HC, TD, FKD, BZG, JFH, MH, DH, CNH, MH, DSJ, XJJ, RJ, MK, LK, BL, LC, JL, WJL, KDL, GM, MM, GM (Mills), JA, XFW, EN, BO, CP, PIP, OP, CR, CY, FL, JG, JC, LYS, YS, SRT, QQW, WHQ, XMW, ZFW, LW, XFW, ZJW, PHX, FMY, QZ, YLZ and MZ contributed to the field observations, laboratory measurements and/or modelling. ZS, SG, RMH, ZT, JL, OW, JA, JB, WJB, DC, DCC, HC, TD, RD, FKD, PQF, MFG, DBG, JFH, KBH, MH, DH, CNH, MH, XJJ, RJ, MK, FJK, LK, ACL, JL, ML, KL, GrM, GoM, MM, PM, EN, FO, PIP, CP, CR, ARR, LYS, GYS, DoS, DaS, YS, XJW, JFL, BB, QC, ZWS, ST, SRT, XMW, ZFW, LW, ZJW, PHX, QZ, YHZ and MZ contributed to the funding applications, programme meetings and relevant programme research and/or supervision.

Competing interests. The authors declare that they have no conflict of interest. 
Special issue statement. This article is part of the special issue "In-depth study of air pollution sources and processes within Beijing and its surrounding region (APHH-Beijing) (ACP/AMT interjournal SI)". It is not associated with a conference.

Acknowledgements. Funding is provided by UK Natural Environment Research Council, Medical Research Council and Natural Science Foundation of China under the framework of Newton Innovation Fund (NE/N007190/1 (Roy M. Harrison, Zongbo Shi, William J. Bloss); NE/N007077/1 (William J. Bloss)); NE/N00700X/1 (Sue Grimmond), NE/N007018/1 (Frank J. Kelly); NSFC Grant 81571130100 (Tong Zhu), NE/N007115/1 (Alastair C. Lewis, Andrew R. Rickard, David C. Carslaw); NE/N006917/1 (James Lee, Jacqueline F. Hamilton, Rachel E. Dunmore); NE/N007123/1 (James Allan, Carl Percival, Gordon McFiggans, Hugh Coe); NE/N00695X/1 (Carl Percival, Hugh Coe, Gordon McFiggans, James Allan); NE/N006976/1 (C. Nicholas Hewitt, Oliver Wild); NE/N006925/1 (Oliver Wild); NE/N006895/1 (Dwayne Heard, Lisa Whalley); NE/N00714X/1 (Daobo Guan), NE/N007182/1 (Miranda Loh); NSFC 41571130024 (Pingqing Fu) and NE/N006879/1 (Paul I. Palmer). Other Grant supports from Newton Fund/Met Office CSSP-China (Sue Grimmond; Ruth Doherty and Zongbo Shi), Royal Society Challenge Grant (CHG/R1/17003, Paul I. Palmer) and NERC (NE/R005281/1, Zongbo Shi) are acknowledged. Field help from Hong Ren, Qiaorong Xie, Wanyu Zhao, Linjie Li, Ping Li and Shengjie Hou from IAP, Kjell zum Berge, Ting Sun at Reading University, Wu Chen, Yanwen Wang, Yunfei Fan, Teng Wang, Xi Che, Tao Xue, Pengfei Liang, Yingruo Li, Xinyan $\mathrm{Hu}$ and Xinghua Qiu from Peking University, Li Yan, Hanbin Zhang, Yutong Cai and Bingling Zhou from King's College London, Anika Krause from Cambridge University is also acknowledged. Many other staff and students from different institutions also contributed to the field campaigns and programme.

Financial support. This research has been supported by the Natural Environment Research Council (grant nos. NE/N007190/1, NE/N007077/1, NE/N00700X/1, NE/N007018/1, NE/N007115/1, NE/N006917/1, NE/N007123/1, NE/N00695X/1, NE/N006976/1, NE/N006895/1, NE/N00714X/1, NE/N007182/1, NE/N006925/1, NE/N006879/1, NE/R005281/1, and NE/N006879/1), the National Natural Science Foundation of China (grant nos. 81571130100 and 41571130024) and the Royal Society (grant no. CHG/R1/17003).

Review statement. This paper was edited by Delphine Farmer and reviewed by three anonymous referees.

\section{References}

Beck, C. and Philipp, A.: Evaluation and comparison of circulation type classifications for the European domain, Phys. Chem. Earth, 35, 374-387, 2010.

Beekmann, M., Prévôt, A. S. H., Drewnick, F., Sciare, J., Pandis, S. N., Denier van der Gon, H. A. C., Crippa, M., Freutel, F., Poulain, L., Ghersi, V., Rodriguez, E., Beirle, S., Zotter, P., von der
Weiden-Reinmüller, S.-L., Bressi, M., Fountoukis, C., Petetin, H., Szidat, S., Schneider, J., Rosso, A., El Haddad, I., Megaritis, A., Zhang, Q. J., Michoud, V., Slowik, J. G., Moukhtar, S., Kolmonen, P., Stohl, A., Eckhardt, S., Borbon, A., Gros, V., Marchand, N., Jaffrezo, J. L., Schwarzenboeck, A., Colomb, A., Wiedensohler, A., Borrmann, S., Lawrence, M., Baklanov, A., and Baltensperger, U.: In situ, satellite measurement and model evidence on the dominant regional contribution to fine particulate matter levels in the Paris megacity, Atmos. Chem. Phys., 15, 9577-9591, https://doi.org/10.5194/acp-15-9577-2015, 2015.

Bohn, B., Heard, D. E., Mihalopoulos, N., Plass-Dülmer, C., Schmitt, R., and Whalley, L. K.: Characterisation and improvement of $j\left(\mathrm{O}^{1} \mathrm{D}\right)$ filter radiometers, Atmos. Meas. Tech., 9, 34553466, https://doi.org/10.5194/amt-9-3455-2016, 2016.

Bohnenstengel, S. I., Belcher, S. E., Aiken, A., Allan, J. D., Allen, G., Bacak, A., Bannan, T. J., Barlow, J. F., Beddows, D. C. S., Bloss, W. J., Booth, A. M., Chemel, C., Coceal, O., Di Marco, C. F., Dubey, M. K., Faloon, K. H., Fleming, Z. L., Furger, M., Gietl, J. K., Graves, R. R., Green, D. C., Grimmond, C. S. B., Halios, C. H., Hamilton, J. F., Harrison, R. M., Heal, M. R., Heard, D. E., Helfter, C., Herndon, S. C., Holmes, R. E., Hopkins, J. R., Jones, A. M., Kelly, F. J., Kotthaus, S., Langford, B., Lee, J. D., Leigh, R. J., Lewis, A. C., Lidster, R. T.,Lopez-Hilfiker, F. D., McQuaid, J. B., Mohr, C., Monks, P. S., Nemitz, E., Ng, N. L., Percival, C. J., Prevot, A. S. H., Ricketts, H. M. A., Sokhi, R., Stone, D., Thornton, J. A., Tremper, A. H., Valach, A. C., Visser, S., Whalley, L. K., Williams, L. R., Xu, L., Young, D. E., and Zotter, P.: Meteorology, air quality, and health in London: The ClearfLo project, B. Am. Meteorol Soc., 96, 779-804, 2014.

Brook, R. D., Brook, J. R., Urch, B., Vincent, R., Rajagopalan, S., and Silverman F.: Inhalation of fine particulate air pollution and ozone causes acute arterial vasoconstriction in healthy adults, Circulation, 105, 1534-1536, 2002.

Chen, Y., Wenger, J. C., Yang, F., Cao, J., Huang, R., Shi, G., Zhang, S., Tian, M., and Wang H.: Source characterization of urban particles from meat smoking activities in Chongqing, China using single particle aerosol mass spectrometry, Environ. Pollut., 228, 92-101, 2017.

Coyle, M., Nemitz, E., Storeton-West, R., Fowler, D., and Cape, J. N.: Measurements of ozone deposition to a potato canopy, Agric. Forest Meteorol., 149, 655-666, https://doi.org/10.1016/j.agrformet.2008.10.020, 2009.

Crilley, L. R., Kramer, L., Pope, F. D., Whalley, L. K., Cryer, D. R., Heard, D. E., Lee, J. D., Reed, C., and Bloss, W. J.: On the interpretation of in situ HONO observations via photochemical steady state., Faraday. Discuss., 189, 191-212, 2016.

Cryer, D. R.: Measurements of hydroxyl radical reactivity and formaldehyde in the atmosphere, $\mathrm{PhD}$ Thesis, University of Leeds, 2016.

Dee, D. P., Uppala, S. M., Simmons, A. J., Berrisford, P., Poli, P., Kobayashi, S., Andrae, U., Balmaseda, M. A., Balsamo, G., Bauer, P., Bechtold, P., Beljaars, A. C. M., van de Berg, L., Bidlot, J., Bormann, N., Delsol, C., Dragani, R., Fuentes, M., Geer, A. J., Haimberger, L., Healy, S. B., Hersbach, H., Hólm, E. V., Isaksen, L., Kållberg, P., Köhler, M., Matricardi, M., McNally, A. P., Monge-Sanz, B. M., Morcrette, J.-J., Park, B.-K., Peubey, C., de Rosnay, P., Tavolato, C., Thépaut, J.-N., and Vitart, F.: The ERA-Interim reanalysis: configuration and performance of the 
data assimilation system, Q. J. Roy. Meteorol. Soc., 137, 553597, 2011.

Demuzere, M., Kassomenos, P., and Philipp, A.: The COST733 circulation type classification software: an example for surface ozone concentrations in Central Europe, Theor. Appl. Climatol., 105, 143-166, 2011.

Deventer, M. J., El-Madany, T., Griessbaum, F., and Klemm, O.: One-year measurement of size-resolved particle fluxes in an urban area, Tellus B, 67, 25531, https://doi.org/10.3402/tellusb.v67.25531, 2015.

Du, W., Zhao, J., Wang, Y., Zhang, Y., Wang, Q., Xu, W., Chen, C., Han, T., Zhang, F., Li, Z., Fu, P., Li, J., Wang, Z., and Sun, Y.: Simultaneous measurements of particle number size distributions at ground level and $260 \mathrm{~m}$ on a meteorological tower in urban Beijing, China, Atmos. Chem. Phys., 17, 6797-6811, https://doi.org/10.5194/acp-17-6797-2017, 2017.

Du, H., Li, J., Chen, X., Wang, Z., Sun, Y., Fu, P., Li, J., Gao, J., and Wei, Y.: Modeling of aerosol property evolution during winter haze episodes over a megacity cluster in northern China: Roles of regional transport and heterogeneous reactions, Atmos. Chem. Phys. Discuss., https://doi.org/10.5194/acp-2018-1189, in review, 2018.

Duan, J., Qin, M., Ouyang, B., Fang, W., Li, X., Lu, K., Tang, K., Liang, S., Meng, F., Hu, Z., Xie, P., Liu, W., and Häsler, R.: Development of an incoherent broadband cavityenhanced absorption spectrometer for in situ measurements of $\mathrm{HONO}$ and $\mathrm{NO}_{2}$, Atmos. Meas. Tech., 11, 4531-4543, https://doi.org/10.5194/amt-11-4531-2018, 2018.

Dunmore, R. E., Hopkins, J. R., Lidster, R. T., Lee, J. D., Evans, M. J., Rickard, A. R., Lewis, A. C., and Hamilton, J. F.: Diesel-related hydrocarbons can dominate gas phase reactive carbon in megacities, Atmos. Chem. Phys., 15, 9983-9996, https://doi.org/10.5194/acp-15-9983-2015, 2015.

El zein, A., Dunmore, R. E., Ward, M. W., Hamilton, J. F., and Lewis, A. C.: Variability of polycyclic aromatic hydrocarbons and their oxidative derivatives in wintertime Beijing, China, Atmos. Chem. Phys. Discuss., https://doi.org/10.5194/acp-2019120, in review, 2019.

Fu, T. M., Jacob, D. J., Palmer, P. I., Chance, K., Wang, Y. X., Barletta, B., Blake, D. R., Stanton, J. C., and Pilling, M. J.: Space-based formaldehyde measurements as constraints on volatile organic compound emissions in east and south Asia and implications for ozone, J.Geophys. Res.-Atmos., 112, D06312, https://doi.org/10.1029/2006JD007853, 2007.

GBD MAPS Working Group: Burden of Disease Attributable to Coal-Burning and Other Major Sources of Air Pollution in China, Special Report 20, Health Effects Institute, Boston, MA, 2016.

Ge, B., Sun, Y., Liu, Y., Dong, H., Ji, D., Jiang, Q., Li, J., and Wang, Z.: Nitrogen dioxide measurement by cavity attenuated phase shift spectroscopy (CAPS) and implications in ozone production efficiency and nitrate formation in Beijing, China, J. Geophys. Res., 118, 9499-9509, https://doi.org/10.1002/jgrd.50757, 2013.

Gerbig, C., Schmitgen, S., Kley, D., Volz, T., and Dewey, K.: An improved fast-response vacuum-UV resonance fluorescence CO instrument, J. Geophys. Res., 104, 1699-1704, 1999.

Guan, D., Su, X., Zhang, Q., Peters, G. P., Liu, Z., Lei, Y., and He, K.: The socioeconomic drivers of China's pri- mary $\mathrm{PM}_{2.5}$ emission, Environ. Res. Lett, 9, 024010, https://doi.org/10.1088/1748-9326/9/2/024010, 2014.

Han, T., Liu, X., Zhang, Y., Qu, Y., Gu, J., Ma, Q., Lu, K., Tian, H., Chen, J., Zeng, L., Hu, M., and Zhu, T.: Characteristics of Aerosol Optical Properties and Their Chemical Apportionments during CAREBeijing 2006, Aerosol Air Qual. Res., 14, 1431$1442,2014$.

Han, T., Xu, W., Li, J., Freedman, A., Zhao, J., Wang, Q., Chen, C., Zhang, Y., Wang, Z., Fu, P., Liu, X., and Sun, Y.: Aerosol optical properties measurements by a CAPS single scattering albedo monitor: Comparisons between summer and winter in Beijing, China, J. Geophys. Res., 122, 2513-2526, https://doi.org/10.1002/2016JD025762, 2017.

Högström, U. and Smedman, A.-S.: Accuracy of Sonic Anemometers: Laminar Wind-Tunnel Calibrations Compared to Atmospheric In Situ Calibrations Against a Reference Instrument, Bound.-Lay. Meteorol., 111, 33-54, https://doi.org/10.1023/b:boun.0000011000.05248.47, 2004.

Hollaway, M., Wild, O., Yang, T., Sun, Y., Xu, W., Xie, C., Whalley, L., Slater, E., Heard, D., and Liu, D.: Photochemical impacts of haze pollution in an urban environment, Atmos. Chem. Phys. Discuss., https://doi.org/10.5194/acp-2019-29, in review, 2019.

Hopkins, J. R., Jones, C. E., and Lewis, A. C.: A dual channel gas chromatograph for atmospheric analysis of volatile organic compounds including oxygenated and monoterpene compounds, J. Environ. Monitor., 13, 2268-2276, 2011.

Huang, Z., Zhang, Y., Yan, Q., Zhang, Z., and Wang, X.: Real-time monitoring of respiratory absorption factors of volatile organic compounds in ambient air by proton transfer reaction time-offlight mass spectrometry, J. Hazard. Mater., 320, 547-555, 2016.

Huth, R., Beck, C., Philipp, A., Demuzere, M., Ustrnul, Z., Cahynová, M., Kyselý, J., and Tveito, O. E.: Classifications of atmospheric circulation patterns, Ann. N. Y. Acad. Sci., 1146, 105-152, 2008.

Johnson, T., Capel, J., and Ollison, W.: Measurement of microenvironmental ozone concentrations in Durham, North Carolina, using a 2B Technologies 205 Federal Equivalent Method monitor and an interference-free 2B Technologies 211 monitor, J. Air Waste Manage. Assoc., 64, 360-371, https://doi.org/10.1080/10962247.2013.839968, 2014.

Junninen, H., Ehn, M., Petäjä, T., Luosujärvi, L., Kotiaho, T., Kostiainen, R., Rohner, U., Gonin, M., Fuhrer, K., Kulmala, M., and Worsnop, D. R.: A high-resolution mass spectrometer to measure atmospheric ion composition, Atmos. Meas. Tech., 3, 10391053, https://doi.org/10.5194/amt-3-1039-2010, 2010.

Kotthaus, S. and Grimmond, C. S. B.: Atmospheric boundary layer characteristics from ceilometer measurements part 1: A new method to track mixed layer height and classify clouds, Q. J. Roy. Meteorol. Soc., 144, 1525-1538, https://doi.org/10.1002/qj.3299, 2018a.

Kotthaus, S. and Grimmond, C. S. B.: Atmospheric boundary layer characteristics from ceilometer measurements part 2: Application to London's urban boundary layer, Q. J. Roy. Meteorol. Soc., 144, 1511-1524, https://doi.org/10.1002/qj.3298, 2018b.

Le Breton, M., Bacak, A., Muller, J. B. A., Bannan, T. J., Kennedy, O., Ouyang, B., Xiao, P., Bauguitte, S. J.-B., Shallcross, D. E., Jones, R. L., Daniels, M. J. S., Ball, S. M., and Percival, C. J.: The first airborne comparison of $\mathrm{N}_{2} \mathrm{O}_{5}$ measurements over the 
UK using a CIMS and BBCEAS during the RONOCO campaign, Anal. Methods, 6, 9731-9743, 2014.

Le Breton, M., Wang, Y., Hallquist, Å. M., Pathak, R. K., Zheng, J., Yang, Y., Shang, D., Glasius, M., Bannan, T. J., Liu, Q., Chan, C. K., Percival, C. J., Zhu, W., Lou, S., Topping, D., Wang, Y., Yu, J., Lu, K., Guo, S., Hu, M., and Hallquist, M.: Online gasand particle-phase measurements of organosulfates, organosulfonates and nitrooxy organosulfates in Beijing utilizing a FIGAERO ToF-CIMS, Atmos. Chem. Phys., 18, 10355-10371, https://doi.org/10.5194/acp-18-10355-2018, 2018.

Li, H., Zhang, Q., Duan, F., Zheng, B., and He, K.: The "Parade Blue": effects of short-term emission control on aerosol chemistry, Faraday Discuss., 189, 317-335, 2016.

Li, M., Liu, H., Geng, G., Hong, C., Liu, F., Song, Y., Tong, D., Zheng, B., Cui H., Man, H., Zhang, Q., and He, K.: Anthropogenic emission inventories in China: a review, Nat. Sci. Rev., 4, 834-866, 2017.

Li, Z., Hu, R., Xie, P., Chen, H., Wu, S., Wang, F., Wang, Y., Ling, L., Liu, J., and Liu W.: Development of a portable cavity ring down spectroscopy instrument for simultaneous, in situ measurement of $\mathrm{NO}_{3}$ and $\mathrm{N}_{2} \mathrm{O}_{5}$, Opt. Exp., 26, 433-449, 2018.

Liang, P., Zhu, T., Fang, Y., Li, Y., Han, Y., Wu, Y., Hu, M., and Wang, J.: The role of meteorological conditions and pollution control strategies in reducing air pollution in Beijing during APEC 2014 and Victory Parade 2015, Atmos. Chem. Phys., 17, 13921-13940, https://doi.org/10.5194/acp-17-139212017, 2017.

Lim, S. S., Vos, T., Flaxman, A. D., Danaei, G., Shibuya, K., AdairRohani, H., AlMazroa, M. A., Amann, M., Anderson, H. R., Andrews, K. G., Aryee, M., Atkinson, C., Bacchus, L. J., Bahalim, A. N., Balakrishnan, K., Balmes, J., Barker-Collo, S., Baxter, A., Bell, M. L., Blore, J. D., Blyth, F., Bonner, C., Borges, G., Bourne, R., Boussinesq, M., Brauer, M., Brooks, P., Bruce, N. G., Brunekreef, B., Bryan-Hancock, C., Bucello, C., Buchbinder, R., Bull, F., Burnett, R. T., Byers, T. E., Calabria, B., Carapetis, J., Carnahan, E., Chafe, Z., Charlson, F., Chen, H., Chen, J. S., Cheng, A. T.-A., Child, J. C., Cohen, A., Colson, K. E., Cowie, B. C., Darby, S., Darling, S., Davis, A., Degenhardt, L., Dentener, F., Des Jarlais, D. C., Devries, K., Dherani, M., Ding, E. L., Dorsey, E. R., Driscoll, T., Edmond, K., Ali ,S. E., Engell, R. E., Erwin, P. J., Fahimi, S., Falder, G., Farzadfar, F., Ferrari, A., Finucane, M. M., Flaxman, S., Fowkes, F. G. R., Freedman, G., Freeman, M. K., Gakidou, E., Ghosh, S., Giovannucci, E., Gmel, G., Graham, K., Grainger, R., Grant, B., Gunnell, D., Gutierrez, H. R., Hall, W., Hoek, H. W., Hogan, A., Hosgood III, H. D., Hoy, D., Hu, H., Hubbell, B. J., Hutchings, S. J., Ibeanusi, S. E., Jacklyn, G. L., Jasrasaria, R., Jonas, J. B., Kan, H., Kanis, J. A., Kassebaum, N., Kawakami, N., Khang, Y.-H., Khatibzadeh, S., Khoo, J.-P., Kok, C., Laden, F., Lalloo, R., Lan, Q., Lathlean, T., Leasher, J. L., Leigh, J., Li, Y., Lin, J. K., Lipshultz, S. E., London, S., Lozano, R., Lu, Y., Mak, J., Malekzadeh, R., Mallinger, L., Marcenes, W., March, L., Marks, R., Martin, R., McGale, P., McGrath, J., Mehta, S., Memish, Z. A., Mensah, G. A., Merriman, T. R., Micha, R., Michaud, C., Mishra, V., Hanafiah, K. M., Mokdad, A. A., Morawska, L., Mozaffarian, D., Murphy, T., Naghavi, M., Neal, B., Nelson, P. K., Nolla, J. M., Norman, R., Olives, C., Omer, S. B., Orchard, J., Osborne, R., Ostro, B., Page, A., Pandey, K. D., Parry, C. D. H., Passmore, E., Patra, J., Pearce, N., Pelizzari, P. M., Petzold, M., Phillips, M. R., Pope,
D., Pope III, C. A., Powles, J., Rao, M., Razavi, H., Rehfuess, E. A., Rehm, J. T., Ritz, B., Rivara, F. P., Roberts, T., Robinson, C., Rodriguez-Portales, J. A., Romieu, I., Room, R., Rosenfeld, L. C., Roy, A., Rushton, L., Salomon, J. A., Sampson, U., SanchezRiera, L., Sanman, E., Sapkota, A., Seedat, S., Shi, P., Shield, K., Shivakoti, R., Singh, G. M., Sleet, D. A., Smith, E., Smith, K. R., Stapelberg, N. J. C., Steenland, K., Stöckl, H., Stovner, L. J., Straif, K., Straney, L., Thurston, G. D., Tran, J. H., Van Dingenen, R., van Donkelaar, A., Veerman, J. L., Vijayakumar, L., Weintraub, R., Weissman, M. M., White, R. A., Whiteford, H., Wiersma, S. T., Wilkinson, J. D., Williams, H. C., Williams, W., Wilson, N., Woolf, A. D., Yip, P., Zielinski, J. M., Lopez, A. D., Murray, C. J. L., and Ezzati, M.: A comparative risk assessment of burden of disease and injury attributable to 67 risk factors and risk factor clusters in 21 regions, 1990-2010: a systematic analysis for the Global Burden of Disease Study, Lancet, 380, 2224-2260, 2010.

Lin, W., Huang, W., Zhu, T., Hu, M., Brunekreef, B., Zhang ,Y., Liu, X., Cheng, H., Gehring, U., Li, C., and Tang, X.: Acute respiratory inflammation in children and black carbon in ambient air before and during the 2008 Beijing Olympics, Environ. Health Perspect., 119, 1507-1512, 2011.

Linn, W. S. and Gong Jr., H.: Air pollution, weather stress, and blood pressure, Am. J. Public Health, 91, 1345-1346, 2001.

Liu, D., Whitehead, J., Alfarra, M. R., Reyes-Villegas, E., Spracklen, D. V., Reddington, C. L., Kong, S., Williams, P. I., Ting, Y.-C., Haslett, S., Taylor, J. W., Flynn, M. J., Morgan, W. T., McFiggans, G., Coe, H., and Allan, J. D.: Black-carbon absorption enhancement in the atmosphere determined by particle mixing state, Nat. Geosci., 10, 184-188, 2017.

Liu, D., Joshi, R., Wang, J., Yu, C., Allan, J. D., Coe, H., Flynn, M. J., Xie, C., Lee, J., Squires, F., Kotthaus, S., Grimmond, S., Ge, $\mathrm{X}$., Sun, Y., and Fu, P.: Contrasting physical properties of black carbon in urban Beijing between winter and summer, Atmos. Chem. Phys. Discuss., https://doi.org/10.5194/acp-2018-1142, in review, 2018.

Liu, Y., Zheng, M., Yu, M., Cai, X., Du, H., Li, J., Zhou, T., Yan, C., Wang, X., Shi, Z., Harrison, R. M., Zhang, Q., and He, K.: High-time-resolution source apportionment of $\mathrm{PM}_{2.5}$ in Beijing with multiple models, Atmos. Chem. Phys., 19, 6595-6609, https://doi.org/10.5194/acp-19-6595-2019, 2019.

Lozano, R., Naghavi, M., Foreman, K., Lim, S., Shibuya, K., Aboyans, V., Abraham, J., Adair, T., Aggarwal, R., Ahn, S. Y., AlMazroa, M. A., Alvarado, M., Anderson, H. R., Anderson, L. M., Andrews, K. G., Atkinson, C., Baddour, L. M., Barker-Collo, S., Bartels, D. H., Bell, M. L., Benjamin, E. J., Bennett, D., Bhalla, K., Bikbov, B., Abdulhak, A. B., Birbeck, G., Blyth, F., Bolliger, I., Boufous, S., Bucello, C., Burch, M., Burney, P., Carapetis, J., Chen, H., Chou, D., Chugh, S. S., Coffeng, L. E., Colan, S. D., Colquhoun, S., Colson, K. E., Condon, J., Connor, M. D., Cooper, L. T., Corriere, M., Cortinovis, M., de Vaccaro, K. C., Couser, W., Cowie, B. C., Criqui, M. H., Cross, M., Dabhadkar, K. C., Dahodwala, N., De Leo, D., Degenhardt, L., Delossantos, A., Denenberg, J., Des Jarlais, D. C., Dharmaratne, S. D., Dorsey, E. R., Driscoll, T., Duber, H., Ebel, B., Erwin, P. J., Espindola, P., Ezzati, M., Feigin, V., Flaxman, A. D., Forouzanfar, M. H., Fowkes, F. G. R., Franklin, R., Fransen, M., Freeman, M. K., Gabriel, S. E., Gakidou, E., Gaspari, F., Gillum, R. F., Gonzalez-Medina, D., Halasa, Y. A., Haring, D., Harrison, J. E., 
Havmoeller, R., Hay, R. J., Hoen, B., Hotez, P. J., Hoy, D., Jacobsen, K. H., James, S. L., Jasrasaria, R., Jayaraman, S., Johns, N., Karthikeyan, G., Kassebaum, N., Keren, A., Khoo, J.-P., Knowlton, L. M., Kobusingye, O., Koranteng, A., Krishnamurthi, R., Lipnick, M., Lipshultz, S. E., Ohno, S. L., Mabweijano, J., MacIntyre, M. F., Mallinger, L., March, L., Marks, G. B., Marks, R., Matsumori, A., Matzopoulos, R., Mayosi, B. M., McAnulty, J. H., McDermott, M. M., McGrath, J., Memish, Z. A., Mensah, G. A., Merriman, T. R., Michaud, C., Miller, M., Miller, T. R., Mock, C., Mocumbi, A. O., Mokdad, A. A., Moran, A., Mulholland, K., Nair, M. N., Naldi, L., Narayan, K. M. V., Nasseri, K., Norman, P., O'Donnell, M., Omer, S. B., Ortblad, K., Osborne, R., Ozgediz, D., Pahari, B., Pandian, J. D., Rivero, A. P., Padilla, R. P., Perez-Ruiz, F., Perico, N., Phillips, D., Pierce, K., Pope III, C. A., Porrini, E., Pourmalek, F., Raju, M., Ranganathan, D., Rehm, J. T., Rein, D. B., Remuzzi, G., Rivara, F. P., Roberts, T., Rodriguez De León, F., Rosenfeld, L. C., Rushton, L., Sacco, R. L., Salomon, J. A., Sampson, U., Sanman, E., Schwebel, D. C., Segui-Gomez, M., Shepard, D. S., Singh, D., Singleton, J., Sliwa, K., Smith, E., Steer, A., Taylor, J. A., Thomas, B., Tleyjeh, I. M., Towbin, J. A., Truelsen, T., Undurraga, E. A., Venketasubramanian, N., Vijayakumar, L., Vos, T., Wagner, G. R., Wang, M., Wang, W., Watt, K., Weinstock, M. A., Weintraub, R., Wilkinson, J. D., Woolf, A. D., Wulf, S., Yeh, P.-H., Yip, P., Zabetian, A., Zheng, Z.-J., Lopez, A. D., and Murray C. J. L.: Global and regional mortality from 235 causes of death for 20 age groups in 1990 and 2010: a systematic analysis for the Global Burden of Disease Study 2010, The Lancet, 380, 2095-2128, 2013.

Lu, K., Guo, S., Tan, Z., Wang, H., Shang, D., Liu, Y., Li, Xin, Wu, Z., Hu, M., and Zhang, Y.: Exploring the atmospheric free radical chemistry in China: the self-cleansing capacity and the formation of secondary air pollution, Nat. Sci. Rev., 0, 1-16, https://doi.org/10.1093/nsr/nwy073, 2018.

Lu, K. D., Rohrer, F., Holland, F., Fuchs, H., Bohn, B., Brauers, T., Chang, C. C., Häseler, R., Hu, M., Kita, K., Kondo, Y., Li, X., Lou, S. R., Nehr, S., Shao, M., Zeng, L. M., Wahner, A., Zhang, Y. H., and Hofzumahaus, A.: Observation and modelling of $\mathrm{OH}$ and $\mathrm{HO}_{2}$ concentrations in the Pearl River Delta 2006: a missing $\mathrm{OH}$ source in a VOC rich atmosphere, Atmos. Chem. Phys., 12, 1541-1569, https://doi.org/10.5194/acp-12-1541-2012, 2012.

Lyu, R., Shi, Z., Alam, M. S., Wu, X., Liu, D., Vu, T. V., Stark, C., Fu, P., Feng, Y., and Harrison, R. M.: Insight into the Composition of Organic Compounds $\left(\geq \mathrm{C}_{6}\right)$ in $\mathrm{PM}_{2.5}$ in Wintertime in Beijing, China, Atmos. Chem. Phys. Discuss., https://doi.org/10.5194/acp-2018-1273, in review, 2019.

McDermitt, D., Burba, G., Xu, L., Anderson, T., Komissarov, A., Riensche, B., Schedlbauer, J., Starr, G., Zona, D., Oechel, W., Oberbauer, S., and Hastings, S.: A new low-power, open-path instrument for measuring methane flux by eddy covariance, Appl. Phys. B, 102, 391-405, https://doi.org/10.1007/s00340010-4307-0, 2011.

McManus, J. B., Zahniser, M. S., Nelson, D. D., Shorter, J. H., Herndon, S. C., Wood, E. C., and Wehr, R.: Application of quantum cascade lasers to high-precision atmospheric trace gas measurements, Opt. Eng., 49, 111124, https://doi.org/10.1117/1.3498782, 2010.

Meng, Z., Xu, X., Lin, W., Ge, B., Xie, Y., Song, B., Jia, S., Zhang, R., Peng, W., Wang, Y., Cheng, H., Yang, W., and Zhao, H.: Role of ambient ammonia in particulate ammonium formation at a ru- ral site in the North China Plain, Atmos. Chem. Phys., 18, 167184, https://doi.org/10.5194/acp-18-167-2018, 2018.

Miao, Y., Guo, J., Liu, S., Liu, H., Li, Z., Zhang, W., and Zhai, P.: Classification of summertime synoptic patterns in Beijing and their associations with boundary layer structure affecting aerosol pollution, Atmos. Chem. Phys., 17, 3097-3110, https://doi.org/10.5194/acp-17-3097-2017, 2017.

Mills, G. P., Hiatt-Gipson, G. D., Bew, S. P., and Reeves, C. E.: Measurement of isoprene nitrates by GCMS, Atmos. Meas. Tech., 9, 4533-4545, https://doi.org/10.5194/amt-9-4533-2016, 2016.

Moore, E., Chatzidiakou, L., Jones, R. L., Smeeth, L., Beevers, S., Kelly, F. J., Quint, J. K., and Barratt, B.: Linking e-health records, patientreported symptoms and environmental exposure data to characterise and model COPD exacerbations: protocol for the COPE study, BMJ Open, 6, e011330, https://doi.org/10.1136/bmjopen-2016-011330, 2016.

Nemitz, E., Hargreaves, K. J., McDonald, A. G., Dorsey, J. R., and Fowler, D.: Micrometeorological measurements of the urban heat budget and $\mathrm{CO}_{2}$ emissions on a city scale, Environ. Sci. Technol., 36, 3139-3146, 2002.

Nemitz, E., Jimenez, J. L., Huffman, J. A., Ulbrich, I. M., Canagaratna, M. R., Worsnop, D. R., and Guenther, A. B.: An eddycovariance system for the measurement of surface/atmosphere exchange fluxes of submicron aerosol chemical species - first application above an urban area, Aerosol Sci. Technol., 42, 636657, 2008.

OECD: The economic consequences of outdoor air pollution - policy highlights, OECD Publishing, Paris, https://doi.org/10.1787/9789264257474-en, 2016.

Pan, X., Ge, B., Wang, Z., Tian, Y., Liu, H., Wei, L., Yue, S., Uno, I., Kobayashi, H., Nishizawa, T., Shimizu, A., Fu, P., and Wang, Z.: Synergistic effect of water-soluble species and relative humidity on morphological changes in aerosol particles in the Beijing megacity during severe pollution episodes, Atmos. Chem. Phys. 19, 219-232, https://doi.org/10.5194/acp-19-219-2019, 2019.

Pang, X., Lewis, A. C., Rickard, A. R., Baeza-Romero, M. T., Adams, T. J., Ball, S. M., Daniels, M. J. S., Goodall, I. C. A., Monks, P. S., Peppe, S., Ródenas García, M., Sánchez, P., and Muñoz, A.: A smog chamber comparison of a microfluidic derivatisation measurement of gas-phase glyoxal and methylglyoxal with other analytical techniques, Atmos. Meas. Tech., 7, 373-389, https://doi.org/10.5194/amt-7-373-2014, 2014.

Palmer, P. I., Jacob, D. J., Fiore, A. M., Martin, R. V., Chance, K., and Kurosu, T. P.: Mapping isoprene emissions over North America using formaldehyde column observations from space, J. Geophys. Res.-Atmos., 108, D6, https://doi.org/10.1029/2002JD002153, 2003.

Petäjä, T., Mordas, G., Manninen, H., Aalto, P. P., Hämeri, K., and Kulmala, M.: Detection Efficiency of a Water-Based TSI Condensation Particle Counter 3785, Aerosol Sci. Technol., 40, 1090-1097, https://doi.org/10.1080/02786820600979139, 2006.

Philipp, A., Bartholy, J., Erpicum, M., Esteban, P., Fettweis, X., James, P., Jourdain, S., Kreienkamp, F., Krennert, T., Lykoudis, S., Michalides, S. C., Pianko-Kluczynska, K., Post, P., Álvarez, D. R., Schiemann, R., Spekat, A., and Tymvios, F. S.: Cost733cat - A database of weather and circulation type classifications, Phys. Chem. Earth, 35, 360-373, 2010. 
Philipp, A., Beck, C., Huth, R., and Jacobeit, J.: Development and comparison of circulation type classifications using the COST 733 dataset and software, Int. J. Climatol., 36, 2673-2691, 2016.

Popoola, O. A., Carruthers, D., Lad, C., Bright, V. B., Mead, I. M., Stettler, M., Saffell, J., and Jones, R. L.: The use of networks of low cost air quality sensors to quantify air quality in urban settings, Atmos. Environ., 194, 58-70, https://doi.org/10.1016/j.atmosenv.2018.09.030, 2018.

Shi, J. P., Harrison, R. M., and Brear, F.: Particle size distribution from a modern heavy duty diesel engine, Sci. Total Environ., 235, 305-317, 1999.

Sloan, C. D., Philipp, T. J., Bradshaw, R. K., Chronister, S., Bradford Barber, W., and Johnston, J. D.: Applications of GPStracked personal and fixed-location $\mathrm{PM}_{2.5}$ continuous exposure monitoring, J. Air Waste Manage. Assoc., 66, 53-65, 2016.

Smith, K. R., Edwards, P. M., Evans, M. J., Lee, J. D., Shaw, M. D., Squires, F., Wilde, S., and Lewis, A. C.: Clustering approaches to improve the performance of low cost air pollution sensors, Faraday Discuss., 200, 321-637, https://doi.org/10.1039/C7FD00020K, 2017.

Smith, K. R., Edwards, P. M., Ivatt, P. D., Lee, J. D., Squires, F., Dai, C., Peltier, R. E., Evans, M. J., Sun, Y., and Lewis, A. C.: An improved low-power measurement of ambient $\mathrm{NO}_{2}$ and $\mathrm{O}_{3}$ combining electrochemical sensor clusters and machine learning, Atmos. Meas. Tech., 12, 1325-1336, https://doi.org/10.5194/amt12-1325-2019, 2019.

Stone, D., Whalley, L. K., Ingham, T., Edwards, P. M., Cryer, D. R., Brumby, C. A., Seakins, P. W., and Heard, D. E.: Measurement of $\mathrm{OH}$ reactivity by laser flash photolysis coupled with laser-induced fluorescence spectroscopy, Atmos. Meas. Tech., 9, 2827-2844, https://doi.org/10.5194/amt-9-2827-2016, 2016.

Storer, M., Salmond, J., Dirks, K. N., Kingham, S., and Epton, M.: Mobile selected ion flow tube mass spectrometry (SIFTMS) devices and their use for pollution exposure monitoring in breath and ambient air-pilot study, J. Breath Res., 8, 037106, https://doi.org/10.1088/1752-7155/8/3/037106, 2014

Sun, Y. L., Wang, Z., Dong, H., Yang, T., Li, J., Pan, X., Chen, P., and Jayne, J. T.: Characterization of summer organic and inorganic aerosols in Beijing, China with an Aerosol Chemical Speciation Monitor, Atmos. Environ., 51, 250-259, 2012.

Sun, Y., Du, W., Fu, P., Wang, Q., Li, J., Ge, X., Zhang, Q., Zhu, C., Ren, L., Xu, W., Zhao, J., Han, T., Worsnop, D. R., and Wang, Z.: Primary and secondary aerosols in Beijing in winter: sources, variations and processes, Atmos. Chem. Phys., 16, 8309-8329, https://doi.org/10.5194/acp-16-8309-2016, 2016.

Taiwo, A. M., Beddows, D. C. S., Calzolai, G., Harrison, R. M., Lucarelli, F., Nava, S., Shi, Z., Valli, G., and Vecchi, R.: Receptor modelling of airborne particulate matter in the vicinity of a major steelworks site, Sci. Total Environ., 490, 488-500, 2014.

Tan, Z., Fuchs, H., Lu, K., Hofzumahaus, A., Bohn, B., Broch, S., Dong, H., Gomm, S., Häseler, R., He, L., Holland, F., Li, X., Liu, Y., Lu, S., Rohrer, F., Shao, M., Wang, B., Wang, M., Wu, Y., Zeng, L., Zhang, Y., Wahner, A., and Zhang, Y.: Radical chemistry at a rural site (Wangdu) in the North China Plain: observation and model calculations of $\mathrm{OH}, \mathrm{HO}_{2}$ and $\mathrm{RO}_{2}$ radicals, Atmos. Chem. Phys., 17, 663-690, https://doi.org/10.5194/acp17-663-2017, 2017.

Tao, S., Ru, M. Y., Du, W., Zhu, X., Zhong, Q. R., Li, B. G., Shen, G. F., Pan, X. L., Meng, W. J., Chen, Y. L., Shen, H. Z., Lin, N.,
Su, S., Zhuo, S. J., Huang, T. B., Xu, Y., Yun, X., Liu, J. F., Wang, X. L., Liu, W. X., Chen, H. F., and Zhu, D. Q.: Quantifying the Rural Residential Energy Transition in China from 1992 to 2012 through a Representative National Survey, Nat. Energy, 3, 567 573, 2018.

Tveito, O. E. and Huth, R.: Circulation-type classifications in Europe: results of the COST 733 Action, Int. J. Climatol., 36, 26712672, 2016.

Vanhanen, J., Mikkilä, J., Lehtipalo, K., Sipilä, M., Manninen, H. E., Siivola, E., Petäjä, T., and Kulmala, M.: Particle size magnifier for nano-CN detection, Aerosol Sci. Tech., 45, 533-542, 2011.

Vaughan, A. R., Lee, J. D., Misztal, P. K., Metzger, S., Shaw, M. D., Lewis, A. C., Purvis, R. M., Carslaw, D. C., Goldstein, A. H., Hewitt, C. N., Davison, B., Beeversh, S. D., and Karl, T. G.: Spatially resolved flux measurements of $\mathrm{NO}_{x}$ from London suggest significantly higher emissions than predicted by inventories, Faraday Discuss., 189, 455-472, https://doi.org/10.1039/C5FD00170F, 2016.

Vu, T. V., Shi, Z., Cheng, J., Zhang, Q., He, K., Wang, S., and Harrison, R. M.: Assessing the impact of Clean Air Action Plan on Air Quality Trends in Beijing Megacity using a machine learning technique, Atmos. Chem. Phys. Discuss., https://doi.org/10.5194/acp-2019-173, in review, 2019.

Wang, H., Lu, K., Chen, X., Zhu, Q., Wu, Z., Wu, Y., and Sun, K.: Fast particulate nitrate formation via $\mathrm{N}_{2} \mathrm{O}_{5}$ uptake aloft in winter in Beijing, Atmos. Chem. Phys., 18, 10483-10495, https://doi.org/10.5194/acp-18-10483-2018, 2018.

Wang, J., Zhang, Q., Chen, M.-D., Collier, S., Zhou, S., Ge, X., Xu, J., Shi, J., Xie, C., Hu, J., Ge, S., Sun, Y., and Coe, H.: First chemical characterization of refractory black carbon aerosols and associated coatings over the Tibetan Plateau (4730 m a.s.1.), Environ. Sci. Technol., 51, 14072-14082, 2017.

Wang, J., Liu, D., Ge, X., Wu, Y., Shen, F., Chen, M., Zhao, J., Xie, C., Wang, Q., Xu, W., Zhang, J., Hu, J., Allan, J., Joshi, R., $\mathrm{Fu}, \mathrm{P}$. , Coe, H., and Sun, Y.: Characterization of black carboncontaining fine particles in Beijing during wintertime, Atmos. Chem. Phys., 19, 447-458, https://doi.org/10.5194/acp-19-4472019, 2019.

Wang, M., Zhu, T., Zheng, J., Zhang, R. Y., Zhang, S. Q., Xie, X. X., Han, Y. Q., and Li, Y.: Use of a mobile laboratory to evaluate changes in on-road air pollutants during the Beijing 2008 Summer Olympics, Atmos. Chem. Phys., 9, 8247-8263, https://doi.org/10.5194/acp-9-8247-2009, 2009.

Wang, M., Shao, M., Chen, W., Lu, S., Liu, Y., Yuan, B., Zhang, Q., Zhang, Q., Chang, C.-C., Wang, B., Zeng, L., Hu, M., Yang, Y., and Li, Y.: Trends of non-methane hydrocarbons (NMHC) emissions in Beijing during 2002-2013, Atmos. Chem. Phys., 15, 1489-1502, https://doi.org/10.5194/acp-15-1489-2015, 2015.

Wang, Q., Sun, Y., Jiang, Q., Du, W., Sun, C., Fu, P., and Wang, Z.: Chemical composition of aerosol particles and light extinction apportionment before and during the heating season in Beijing, China, J. Geophys. Res., 120, 12708-12722, https://doi.org/10.1002/2015JD023871, 2015.

Wang, T., Nie, W., Gao, J., Xue, L. K., Gao, X. M., Wang, X. F., Qiu, J., Poon, C. N., Meinardi, S., Blake, D., Wang, S. L., Ding, A. J., Chai, F. H., Zhang, Q. Z., and Wang, W. X.: Air quality during the 2008 Beijing Olympics: secondary pollu- 
tants and regional impact, Atmos. Chem. Phys., 10, 7603-7615, https://doi.org/10.5194/acp-10-7603-2010, 2010.

Wang, W., Shao, L., Xing, J., Li, J., Chang, L., and Li, W.: Physicochemical characteristics of individual aerosol particles during the 2015 China victory day parade in Beijing, Atmosphere, 9, 40, https://doi.org/10.3390/atmos9020040, 2018.

Wang, Y., Zhang, F., Li, Z., Tan, H., Xu, H., Ren, J., Zhao, J., $\mathrm{Du}, \mathrm{W}$., and Sun, Y.: Enhanced hydrophobicity and volatility of submicron aerosols under severe emission control conditions in Beijing, Atmos. Chem. Phys., 17, 5239-5251, https://doi.org/10.5194/acp-17-5239-2017, 2017.

Whalley, L. K., Furneaux, K. L., Goddard, A., Lee, J. D., Mahajan, A., Oetjen, H., Read, K. A., Kaaden, N., Carpenter, L. J., Lewis, A. C., Plane, J. M. C., Saltzman, E. S., Wiedensohler, A., and Heard, D. E.: The chemistry of $\mathrm{OH}$ and $\mathrm{HO}_{2}$ radicals in the boundary layer over the tropical Atlantic Ocean, Atmos. Chem. Phys., 10, 1555-1576, https://doi.org/10.5194/acp10-1555-2010, 2010.

WHO: Ambient air pollution: a global assessment of exposure and burden of disease, ISBN 97892151135 3, 2016a.

WHO: Burden of disease from joint household and ambient air pollution for 2012, available at: https://www.who.int/phe/health_ topics/outdoorair/databases/AP_jointeffect_methods_Nov2016. pdf?ua=1 (last access: 20 May 2019), 2016b.

Wragg, F. P. H., Fuller, S. J., Freshwater, R., Green, D. C., Kelly, F. J., and Kalberer, M.: An automated online instrument to quantify aerosol-bound reactive oxygen species (ROS) for ambient measurement and health-relevant aerosol studies, Atmos. Meas. Tech., 9, 4891-4900, https://doi.org/10.5194/amt-9-4891-2016, 2016.

Wu, J., Li, G., Cao, J., Bei, N., Wang, Y., Feng, T., Huang, R., Liu, S., Zhang, Q., and Tie, X.: Contributions of trans-boundary transport to summertime air quality in Beijing, China, Atmos. Chem. Phys., 17, 2035-2051, https://doi.org/10.5194/acp-172035-2017, 2017.

Wu, Z. J., Poulain, L., Henning, S., Dieckmann, K., Birmili, W., Merkel, M., van Pinxteren, D., Spindler, G., Müller, K., Stratmann, F., Herrmann, H., and Wiedensohler, A.: Relating particle hygroscopicity and CCN activity to chemical composition during the HCCT-2010 field campaign, Atmos. Chem. Phys., 13, 79837996, https://doi.org/10.5194/acp-13-7983-2013, 2013.

Wu, Z. J., Zheng, J., Shang, D. J., Du, Z. F., Wu, Y. S., Zeng, L. M., Wiedensohler, A., and Hu, M.: Particle hygroscopicity and its link to chemical composition in the urban atmosphere of Beijing, China, during summertime, Atmos. Chem. Phys., 16, 11231138, https://doi.org/10.5194/acp-16-1123-2016, 2016.

Xia, Y., Guan, D., Jiang, X., Peng, L., Schroeder, H., and Zhan, Q.: Assessment of socioeconomic costs to China's air pollution, Atmos. Environ., 139, 147-156, 2016.

Xia, Y., Guan, D., Meng, J., Li, Y., and Shan, Y.: Assessment of the pollution-health-economics nexus in China, Atmos. Chem. Phys., 18, 14433-14443, https://doi.org/10.5194/acp-18-144332018, 2018.

Xie, C., Xu, W., Wang, J., Wang, Q., Liu, D., Tang, G., Chen, P., Du, W., Zhao, J., Zhang, Y., Zhou, W., Han, T., Bian, Q., Li, J., Fu, P., Wang, Z., Ge, X., Allan, J., Coe, H., and Sun, Y.: Vertical characterization of aerosol optical properties and brown carbon in winter in urban Beijing, China, Atmos. Chem. Phys., 19, 165179, https://doi.org/10.5194/acp-19-165-2019, 2019.
Yang, G., Wang, Y., Zeng, Y., Gao, G. F., Liang, X., Zhou, M., Wan, X., Yu, S., Jiang, Y., Naghavi, M., Vos, T., Wang, H., Lopez, A. D., and Murray, C. J. L.: Rapid health transition in China, 19902010: findings from the Global Burden of Disease Study 2010, The Lancet, 381, 1987-2015, 2013.

Yu, J., Yan, C., Liu, Y., Li, X., Zhou, T., and Zheng, M.: Potassium: A Tracer for Biomass Burning in Beijing?, Aerosol Air Qual. Res., 18, 2447-2459, 2018.

Yue, S., Ren, H., Fan, S., Sun, Y., Wang, Z., and Fu, P.: Springtime precipitation effects on the abundance of fluorescent biological aerosol particles and HULIS in Beijing, Sci. Rep., 6, 29618, https://doi.org/10.1038/srep29618, 2016.

Zhang, J. B., Xu, Z., Yang, G., and Wang, B.: Peroxyacetyl nitrate (PAN) and peroxypropionyl nitrate (PPN) in urban and suburban atmospheres of Beijing, China, Atmos. Chem. Phys. Discuss., 11, 8173-8206, https://doi.org/10.5194/acpd-11-81732011, 2011.

Zhang, J. P., Zhu, T., Zhang, Q. H., Li, C. C., Shu, H. L., Ying, Y., Dai, Z. P., Wang, X., Liu, X. Y., Liang, A. M., Shen, H. X., and Yi, B. Q.: The impact of circulation patterns on regional transport pathways and air quality over Beijing and its surroundings, Atmos. Chem. Phys., 12, 5031-5053, https://doi.org/10.5194/acp12-5031-2012, 2012.

Zhang, Q., Streets, D. G., Carmichael, G. R., He, K. B., Huo, H., Kannari, A., Klimont, Z., Park, I. S., Reddy, S., Fu, J. S., Chen, D., Duan, L., Lei, Y., Wang, L. T., and Yao, Z. L.: Asian emissions in 2006 for the NASA INTEX-B mission, Atmos. Chem. Phys., 9, 5131-5153, https://doi.org/10.5194/acp-9-5131-2009, 2009.

Zhang, Q., Jiang, X., Tong, D., Davis, S. J., Zhao, H., Geng, G., Feng, T., Zheng, B., Lu, Z., Streets, D. G., Ni, R., Brauer, M., van Donkelaar, A., Martin, R. V., Huo, H., Liu, Z., Pan, D., Kan, H., Yan, Y., Lin, J., He, K., and Guan, D.: Transboundary health impacts of transported global air pollution and international trade, Nature, 543, 705-709, 2017.

Zhang, Y., Ren, H., Sun, Y., Cao, F., Chang, Y., Liu, S., Lee, X., Agrios, K., Kawamura, K., Liu, D., Ren, L., Du, W., Wang, Z., Prevot, A. S. H., Szidat, S., and Fu, P.: High contribution of non-fossil sources to sub-micron organic aerosols in Beijing, China, Environ. Sci. Technol., 51, 7842-7852, https://doi.org/10.1021/acs.est.7b01517, 2017.

Zhang, W., Tong, S., Ge, M., An, J., Shi, Z., Hou, S., Xia, K., Qu, Y., Zhang, H., Chu, B., Sun, Y., and He, H.: Variations and sources of nitrous acid (HONO) during a severe pollution episode in Beijing in winter 2016, Sci. Total Environ., 648, 253-262, 2019.

Zhao, W., Kawamura, K., Yue, S., Wei, L., Ren, H., Yan, Y., Kang, M., Li, L., Ren, L., Lai, S., Li, J., Sun, Y., Wang, Z., and Fu, P.: Molecular distribution and compound-specific stable carbon isotopic composition of dicarboxylic acids, oxocarboxylic acids and a-dicarbonyls in $\mathrm{PM}_{2.5}$ from Beijing, China, Atmos. Chem. Phys., 18, 2749-2767, https://doi.org/10.5194/acp18-2749-2018, 2018.

Zhou, W., Zhao, J., Ouyang, B., Mehra, A., Xu, W., Wang, Y., Bannan, T. J., Worrall, S. D., Priestley, M., Bacak, A., Chen, Q., Xie, C., Wang, Q., Wang, J., Du, W., Zhang, Y., Ge, X., Ye, P., Lee, J. D., Fu, P., Wang, Z., Worsnop, D., Jones, R., Percival, C. J., Coe, H., and Sun, Y.: Production of $\mathrm{N}_{2} \mathrm{O}_{5}$ and $\mathrm{ClNO}_{2}$ in summer in urban Beijing, China, Atmos. Chem. Phys., 18, 11581-11597, https://doi.org/10.5194/acp-18-11581-2018, 2018. 